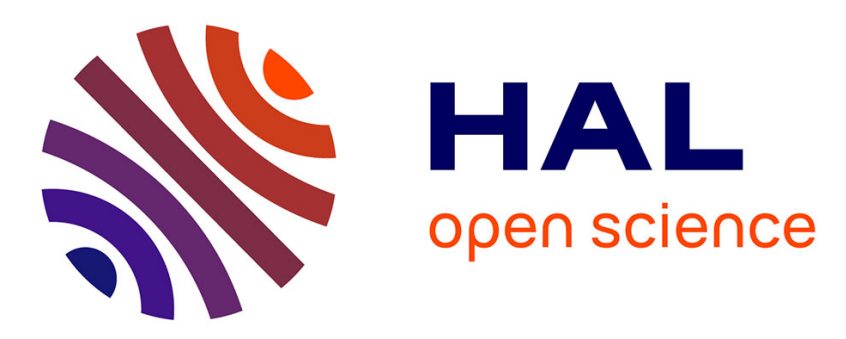

\title{
Historical concepts on the relations between nerves and muscles
}

François Clarac, Jean-Gaël Barbara

\section{To cite this version:}

François Clarac, Jean-Gaël Barbara. Historical concepts on the relations between nerves and muscles.

Brain Research, 2011. halshs-03090670

\section{HAL Id: halshs-03090670 \\ https://shs.hal.science/halshs-03090670}

Submitted on 11 Jan 2021

HAL is a multi-disciplinary open access archive for the deposit and dissemination of scientific research documents, whether they are published or not. The documents may come from teaching and research institutions in France or abroad, or from public or private research centers.
L'archive ouverte pluridisciplinaire HAL, est destinée au dépôt et à la diffusion de documents scientifiques de niveau recherche, publiés ou non, émanant des établissements d'enseignement et de recherche français ou étrangers, des laboratoires publics ou privés. 


\title{
Historical concepts on the relations between nerves and muscles
}

Version auteur de : J.G. Barbara, F. Clarac, 2011, « Historical concepts on the relations between nerves and muscles », Brain Research, 1409, 3-22 (ISSN 0006-8993).

Jean-Gaël Barbara, ${ }^{a^{*}}$ François Clarac, ${ }^{b}$

aUniversité Pierre et Marie Curie, Centre National de la Recherche Scientifique, UMR7102, Case 14, 7 quai Saint Bernard, 75005, Paris and Université Denis Diderot, CNRS UMR 7218, Paris, France, and Université Paris Diderot, UMR7219.

b P3M, CNRS, Université de la Méditerranée, 31 chemin Joseph Aiguier, 13402 Marseille, France

*Corresponding author: Université Pierre et Marie Curie, Centre national de la recherche scientifique, Case 14, 7 quai Saint Bernard, 75005, Paris.

E-mail : jean-gael.barbara@snv.jussieu.fr

Key words: animal spirits, curare, muscular activation, motor units, neuromuscular junction, reflexes, Wallerian degeneration

The separate research programs of J.-G. B. and F.C. are supported by CNRS funds.

\begin{abstract}
This review addresses the history since antiquity of studies on the anatomical and functional relations between nerves and muscles, and the progressive use of newer approaches to this topic. By the Hippocratic era (almost 2,500 years ago) the digestive, circulatory and nervous systems were thought to participate in the production of animal spirits. This concept had strong support for nervous conduction, even after the dawn of electrophysiology in the late 18th $\mathrm{C}$. The idea that these spirits explained the nature of the motor command to muscles continued to prevail until work in the mid-to-late 19th $C$ dispelled the concept of "fluid/spirit" transmission by measurements of nerve "action currents" and conduction velocity. In parallel with this work, the functional relations between nerves and muscles were studied with the use of curare, which continued well into the 20th $\mathrm{C}$. In the late 19th $\mathrm{C}$ the debate was formalized about whether transmission at the motor endplate was electrical or chemical. This continued as the "soup" vs. sparks" battle until, surprisingly, the late 1960s. The concept of the motor unit was introduced in the 1920s, this being defined as a motor neuron in the spinal cord connecting to a specific set of muscle fibers. This development accelerated work on two-way trophic relations between nerve and muscles and their essential plasticity in the face of the demands of usage and disease. Clearly, the relation between nerves and muscles has been on the forefront of neuroscience since antiquity.
\end{abstract}

Abbreviations: CNS, central nervous system; FDL, flexor digitorum longus muscle; MN, motoneuron; MU, motor unit; NMJ, neuromuscular junction

Note: Countries are indicated by their 3-letter ISO-3166 abbreviation. See: http://www.davros.org/misc/iso3166.html 


\section{Contents}

1. Introduction

2. Nervous conduction and muscle excitation

2.1. The concept of "animal spirits"

2.2. Development of anatomy as a science

2.3. Notions about reflexes in the 17 th and 18 th $\mathrm{C}$

2.4. Induction of animal electricity

2.5. CNS neurons and peripheral nerve fibers

3. Neuron theory followed by motoneuron (MN) theory 3.1. Conduction direction and properties of nerves

3.2. Laws about neuronal fiber excitation and muscle contraction

3.3. The neuromuscular junction (NMJ)

3.3.1. Delineation by anatomy

3.3.2. The curare controversy

3.3.3. Subsequent developments: "soup vs. sparks"

3.4. Concept of the motor unit (MU)

4. Trophic aspects of nerve-muscle relations

4.1. Lesions in peripheral nerves

4.2. Nerve degeneration and regeneration

4.3. Crossed regeneration between different muscles

4.4. Muscle-to-nerve trophism

5. Concluding thoughts for what follows

Footnotes

Acknowledgements

References 


\section{Introduction}

The term "motoneuron" (MN) is used today to designate a central nervous system (CNS) neuron whose axon innervates one (and sometimes two) of the body's striated muscles. Typically, the axon ramifies into many axon collaterals each of which innervates a single muscle fiber. The connection between each axon collateral and its muscle fiber is a complex structure, the neuromuscular junction (NMJ). In this introduction to our articles on paths of discovery in MN neurobiology (Stuart et al., 2011), we discuss how biologists, and later anatomists, clinicians (including neurologists and surgeons), pathologists, and physiologists, came to understand the anatomical relations between the CNS and the musculature, and the necessity for reciprocal functional relations between MNs and muscle fibers. Since antiquity, the study of these relations has formed the basis of the later understanding of what came to be defined as a $\mathrm{MN}$, with its function shown to control the development of the force developed by its particular set of muscle fibers and the trophic maintenance of these fibers and viceversa. What follows is thus a fitting prologue to our subsequent four articles (Clarac and Barbara, 2011; Duchateau and Enoka, 2011; Stuart and Brownstone, 2011; Brownstone and Stuart, 2011).

Until the 18th $\mathrm{C}$, the concept of "animal spirits" explained how the higher regions of the nervous structures spread commands to all body regions and controlled the activity of muscles. In the following two centuries, nerve fibers were considered as the specific extensions of cells located in CNS centers, and peripheral nerve conduction was analyzed as an electrical process that resulted in muscle activation. 1 In the 20th $C$, nerve section experiments were undertaken, these involving nerve degeneration and studies of cross innervations between different types of nerves and muscles. MNs and their muscle fibers came to be seen as a single functional unit, the motor unit (MU), the unit of muscular activation, as defined by Charles Sherrington [1857-1952] and his British colleagues in the mid 1920s.

It was generally concluded by the late 19th C that the CNS and the musculature were closely interwined and could not operate without each other. On the one hand, it came to be known that the musculature, like peripheral glands, represented the output of the CNS, and on the other hand, appropriate innervation by MNs was required for muscle activation.

\section{Nervous conduction and muscle excitation}

The medical dogma of antiquity focused mainly on nervous, digestive, muscular and vascular functions, and their multiple and dynamic interrelations. Studying the brain and the nerves, Hippocrates of Cos [ 460 BC- 370 BC], the Greek father of Western medicine (see Gourevitch, 1994), claimed that the brain was the seat of epilepsy. In addition, his "Hippocratic Corpus" (a collection of about 70 medical works) contained many other observations on various kinds of palsies. The brain was considered as the center of psychic functions, although medical explanations relied most heavily on the theory of humors. 2 For Aristotle [384 BC-322 BC], the Greek philosopher of Plato and Socrates lineage, blood vessels were considered to be the most important anatomical elements of the brain, with the apparently homogeneous brain tissue simply thought to cool the blood, together with the lungs. This anatomical emphasis on the blood vessels of the brain was to remain a central anatomical and physiological issue until the late 18th C (Finger, 1994; Barbara, 2008).

Two Greek physicians of Alexandria, Herophilos [335 BC-280 BC] and Erasistratus 
[304-250 BC], made important contributions to the anatomy and the physiology of the nervous system by using dissections of human cadavers and animal vivisection. They distinguished between blood vessels, nerves, and tendons, as well as between motor and sensory nerves. For example, Herophilos described the role of the optic nerve in vision and that of the oculomotor nerves in eye movement. Other anatomical descriptions included those for the cerebellum and the fourth ventricle. 3

\subsection{The concept of "animal spirits"}

This concept, which arose during the "Pre-Galenic" period (see below), was in use until the discovery of "animal electricity" and much later, the idea and demonstration of the nerve impulse. Erasistratus described animal spirits in his theory of nutrition (Dobson, 1927). He proposed that the veins of the liver contained a "natural spirit," which nourished the body, while arteries carried a "vital spirit," which entered the body through the lungs (arteries were thought to carry air because they seemed to be empty during the dissection of human corpses). The vital spirit was carried to the heart and throughout the body by the blood vessels, and to the brain by the carotid arteries, where it became the "psychic pneuma" or "animal spirits". These spirits were thought by "vitalists" (i.e., those in the 17th-19th $\mathrm{C}$ who favoured specific vital forces rather than mechanical or chemical ones) to be located in the various cavities of the brain from whence they sent motor commands back to the body: i.e., by flowing down to the spinal cord in order to contract the muscles.

Galen located his "motor principle" inside the nerves: "I have demonstrated ... that the brain is the principle of nerves, the principle of sensation, and the principle of voluntary movement, that the heart is the principle of arteries and of innate heat ... Any of the senses requires a soft nerve: a nerve since nerves are the organs of sensation, a soft nerve since the sense must be arranged and affected in a particular way for the sensation to occur ... But the soft nerve can be more easily subjected to impressions and the hard nerve can more easily act. This explains why soft nerves are necessary to the senses, and the hard nerves to all other parts" 4 (quoted in Daremberg, 1854). Sensations merged and combined in the "sensorium commune" (brain center where all sensations unify), a concept that was retained well into the 19th C. Galen distinguished between voluntary and non-conscious actions, but he considered that some automatic movements, such as breathing, could also be voluntary on some occasions, as controlled by the soul (voluntary action) (Debru, 1996).

\subsection{Development of anatomy as a science}

In the Renaissance period (14th-16th C), a great revival of anatomical studies occurred and public human cadaver dissections became possible in the Venice Republic and later elsewhere. Galen's errors were pointed out, especially by Andreas Vesalius [1514-1564], the father of modern human anatomy, in Padova, ITA, but also by others in Bologna and Pisa, ITA. Based on observations on his dissected corpses, Vesalius (1543) wrote and illustrated the first comprehensive textbook of anatomy.

Many artists of the Renaissance are known to have made precise anatomical illustrations as based on their own and others' dissection of human cadavers. This group included the multi-talented Leonardo da Vinci [1472-1519]. The Renaissance artists often drew the body without skin (an "ecorché," as in Fig. 1) and they described in great detail the muscles and their insertion onto bones. Muscle function remained much as described by Galen, with an emphasis on function based on muscle shape and 
location in a teleological perspective. The Renaissance ecorché remained a model for centuries in painting, sculpture, and wax pieces (Riva et al., 2010). $\mathbf{5}$

Figure 1 near here

\subsection{Notions about reflexes in the 17 th and 18 th $C$}

In his treatises entitled (in English) "The Passions of the Soul" (1649) and "The Treatise on Man" (1664; see Fig. 2), the French philosopher, René Descartes [1596-1650] (see also Clark, 2006) described two different types of movement: those voluntary involving the soul and those automatic generated by the "machine," the latter meaning the mechanics of the human body: "Among the movements occurring in our body, some do depend on the mind ... Walking, singing, and other similar actions can be done without thinking. The spontaneous reaction involving no thought comes from the machine, when a conscious action and thought are elaborated inside the mind, where the soul is" (see Canguilhem, 1977).

Figure 2 near here

Descartes used many of Galen's ideas in his explanation of sensations and the flow of animal spirits, thus still emphasizing a close relation between blood circulation and the conduction that occurred inside nerves. Descartes' idea was that animal spirits were contained within the nerves and blood vessels before spreading into the body where they could contract muscles and inhibit their antagonist muscles (Fig. 2). Amazingly, this reciprocal coordination of muscle actions described by Descartes was emphasized over three centuries later in Sherrington's classic 1906 monograph, albeit in his "modern" neurophysiological parlance.

In 1628, the renowned English physician, William Harvey [1578-1657], 6 published his treatise on the circulation of the blood. This great discovery, which separated definitively the nervous and cardiovascular systems, was not accepted at first. Most physicists, for example from the Paris Sorbonne University, continued to follow the Greek and Latin dogma and attacked the "circulateurs" (those defending circulation).

Another English physician, William Croone [1633-1684], thought "nervous juice" induced muscle activation by nourishing the inflating muscles. In "De Motu Musculari" ["On the movement of muscles"] (1670), Thomas Willis [1618-1678], yet another English physician, defined the organization of spontaneous and reflex movements. $\mathrm{He}$ described three steps: "In every movement, three things must be considered: First, the origin of action, the first sign of the movement to be performed which always begins in the brain or cerebellum; second, the excitation, the transmission of the movement to all parts of the body, occurring inside the nerves by the motion of the flowing spirits; and third, the motor force itself, the expression of the spirits inside the motor parts as a force of contraction or expansion. From this triple origin arise many species and varieties of movements all different from one another." (see Canguilhem, 1977) The general principles of reflex movement were thus described, and Willis also made clear distinctions between different movements according to the intensity of stimulation required to elicit them and the peripheral nervous pathways so involved.

The debate on muscle activation divided two schools, the "iatrochemists" and the "iatrophysicists" (ІатроS, "iatros" meaning physician) such as the Pisan mathematician/physicist, Giovanni Borelli [1608-1679] and Johannes Kepler [15711630], a German mathematician, astronomer, and astrologer. In his "De Motu Animalium" ["On the movement of animals] (1680/1989), Borelli analysed the movements of animals and the human body, using geometrical and physical 
(dynamical) principles. He provided a rigorous description of locomotion, emphasizing the importance of pelvic rotation and the involvement of joints. Lateral forces and forward propulsion requiring pressure on the supporting leg were described. Borelli did not believe that muscles were animated by etherial agents such as animal spirits or by air. In a classic experiment, he put a struggling animal into water and observed no air bubbles emanating from the active muscles, even when the skin was removed. Accordingly, Borelli concluded that if animal spirits we indeed involved in muscle activation they could not be gaseous!

The mechanism of the conduction of animal spirits inside the nerves remained unclear until the late 18th C. In his 1737 "Biblia Naturae" ["The Book of Nature"], the Dutch biologist and microscopist, Jan Swammerdam [1637-1680], was the first to use the frog sciatic nerve-gastrocnemius preparation, which is still in use four centuries later for both research and teaching (Cobb, 2002). Swammerdam demonstrated rigorously that the volume of the muscle did not change during activation, i.e., he showed that no additional fluid entered the muscle.

Vitalist thinking was evident in the writing of Georg Ernst Stahl [1660-1734], a German chemist and physician, and Claude Perrault [1613-1688], a French architect, anatomist, and physician, even though the latter was a "Cartesian" (i.e., a person who believed in the doctrines of Descartes). Stahl advocated a modification of "phlogiston theory" which in its original form held that all flammable materials contained "phlogiston," a substance without color, odor, taste, and mass that was liberated in burning. Once burned, the "dephlogisticated" substance was held to be in its "true" form. Stahl's believed that all matter, including animals and humans, had a vital force, or a soul of sorts. This force, or soul, controlled bodily functions. In his "Essai de Physique" ["On Physics"]" (1680), Perrault analyzed the movements of plants and animals and made distinctions between those elicited by external stimulation, peripheral and internal sensations controlled by the soul. In Montpellier, a French physician and physiologist, Paul Barthez [1734-1806] wrote several articles in his "Encyclopédie" ["Encyclopedia"] (1751-1772) in which he supported the vitalist concept of motor and sensory actions.

An Armenian-born Italian clinician, anatomist and pathologist, Giorgio Baglivi [16681707] opposed the chemical vitalist doctrine to the extent that he felt that it was incorrect to assign to the humors an exclusive role in controlling bodily functions. Since he believed that the solid parts of organs were more important for their healthy functioning than their fluids, he is considered the leader of the "solidist doctrine" of that time. Later in the 18th C, some materialist philosophers, such as the French physician, Julien Offray de La Mettrie [1709-1751], explained the functions of the body without even referring to control by the soul. In 1747, La Mettrie published "L'Homme Machine" ["Machine Man"], in which the machine was the all-controlling force, and the mind was a figment of the imagination (see Thompson, 1996).

There was, however, experimental work in the 18th C, especially in the Swiss school of Albrecht von Haller [1708-1777], an anatomist, naturalist, physiologist, and poet. He provided a clear distinction between the concepts of irritability (a property of tissues wherein excitation induced movement), and sensitivity (a property wherein excitation induced the sensation of pain). In 1762, von Haller published his famous "Elementa Physiologiae Corpori Humani" ["Elements in the Physiology of the Human Body"], in which he claimed that his experimental method enabled him to combine animist (a soul governing the human body) and vitalist explanations of bodily functions. ${ }^{7}$ In his 
anatomical and physiological work, the French anatomist, Marie-François Xavier Bichat [1771-1802], adopted von Haller's method. He made a distinction between "vie de relation" ["animal life"] and "vie végétative" ["vegetative life"]. His animal (or external) life involved paired organs that controlled movement in the external world (e.g., muscles and sense organs) in contrast to his vegetative (autonomous) life that used single organs of the digestive system to control the internal life of the organism.

The Edinburgh, GBR physician, Robert Whytt [1714-1766], studied hypochondriacal and hysterical patients, while, at the same time undertaking animal experiments on the role of the spinal cord in the decapitated frog. He inserted a fine needle into the spinal cord to destroy its lower neural tissue. The animal's legs became flaccid and unable to react to any stimulus below the sites neural destruction. The spinal cord was thus shown to be necessary for any reflex action that engaged the legs. This observation was confirmed by a German physiologist, Johann August Unzer [1727-1799], and Jiri Prochaska [1749-1820], a Czech-born professor of anatomy, physiology, and ophthalmology in Vienna, AUT8

\subsection{Induction of animal electricity}

By the end of the 18th $C$, the concept of animal spirits became universally obsolete with the discovery and further practical developments of a new form of energy, electricity. The Leyden jar (1745), developed by the Dutch scientist (mathematician, philosopher, physician, astrologer), Pieter van Musschenbroek [1692-1761], became of central importance in animal experimentation. Experiments on electricity were a great scientific adventure for many, with an American of many talents, Benjamin Franklin [1706-1790], on the forefront of the conception of electricity based on positively and negatively charged particles. In 1750, he established his principle of the conservation of electrical charges in long-range phenomena.

In Bologna, ITA Luigi Galvani [1737-1798], a physician and physicist, performed the first experimental work on the electrical activation of frog muscle, using a Leyden jar and other types of electrostatic machines. One of his most famous experiments was undertaken on September 16, 1786. A leg of a pithed frog was hung on a brass hook attached to an iron balcony railing at his home. The electricity produced by the contact between the two metals activated twitches of the leg. Galvani developed a theory in which muscle fibers were considered to be small Leyden jars, the nerve fibers being conductive elements in continuity with the internal structures of muscle. An electrical spark was thought to discharge the muscle fibers thereby inducing activation when the nerve and the muscle interacted. Muscles were thus thought to create their own electricity, which was necessary for their activation. This experiment and its interpretation were published in 1791, with an immediate and profound impact on scientists who were literally awestruck by Galvani's proposal.

An Italian professor of experimental physics at the University of Pavia, Alessandro Volta [1745-1827], was a strong opponent of Galvani's ideas about animal electricity. He argued that Galvani's frog leg served as both a conductor and detector of electricity. He even replaced the frog's leg with saline-soaked paper, and demonstrated the flow of electricity using equipment that he had designed and built in his previous studies. He also showed that cascading a variety of different metals on top of each other (the "Voltaic pile") produced electricity. This led to his development of the electric battery, "... one of the major technological steps in the history of science" (Brazier, 1959). Volta succeeded in the widespread dismissal of Galvani's ideas on animal electricity. In contrast, Mary Brazier [1904-1995], a prominent British/American neuroscience 
historian and electroencephalographer, claimed that Galvani's original experiments were "the dawn of electrophysiology," as we know it today (Brazier, 1984).

In 1825, the Italian physicist, Leopoldo Nobili [1784-1835], built an "astatic" galvanometer (two coils of wire wound in opposite directions), which could record electrical discharges and the electrical responses involved in muscle activation. Carlo Matteucci [1811-1868], an Italian physicist and early neurophysiologist, was the first to again champion the ideas of Galvani. After research on the electric organ of the torpedo fish he studied the source of electricity in the frog nerve-muscle preparation. For this, he used intact humans and a frog preparation consisting of a single nerve that innervated a complete leg below the knee. His findings included " ... current flow between the cut surface of a muscle and its undamaged surface, demonstrated in both animal and man ... the multiplication of current by serial arrangement of cut muscles ... the decrease in this current during tetanus caused by strychnine ... (the germ of the discovery of the action current) ... and ... the ability of a frog's muscle contraction to generate enough electricity to stimulate the nerve of another nerve-muscle preparation which laid across it (the rheoscopic frog)" (Brazier, 1959).

In 1841, Emil du Bois-Reymond [1818-1896], a German physician and physiologist of French name and Swiss descent, was asked by his mentor, Johannes Müller [1801 1858], a renowned German physiologist, comparative anatomist, and ichthyologist, to confirm the experiments of Matteucci. He did this using far more advanced equipment than was available to Matteuci but he disagreed with much outspoken acerbity about Matteucci's ideas on the direction of the flow of electricity during muscle contraction. (For further details about du Bois-Reymond's polemics about Matteucci but nonetheless substantial contributions, see Brazier, 1959). Interestingly both Matteucci and du BoisReymond thought that electrical current was a property of muscle. Matteucci, however, remained confused about the relation between electricity and the vitalist belief in a "nerve force," whereas du Bois-Reymond's improved instrumentation enabled him to lay the groundwork for objective understanding of the nerve "action current." In 1854, Jules Antoine Reginald [1820-1895] measured the potential difference between the intact surface and an inner portion of a muscle and, in 1867, du Bois-Reymond repeated this observation and proposed models of the generation of electricity by tissues, thereby introducing the modern field of electrophysiology.

\subsection{CNS neurons and peripheral nerve fibers}

In the early 19th $\mathrm{C}$, nerve fibers and nerve cells were considered to be two distinct anatomical entities and as such, studied separately: nerves in the periphery and nerve centers in the CNS. The initial microscopic observations were made on peripheral nerves because they could be isolated and observed more easily than CNS nerve

cells. 9 A major point of debate at that time concerned the anatomical and functional relations between nerve fibers and cells. Most anatomists, including Jan Evangelista Purkinje (Purkyně) [1787-1869], a Czech anatomist and professor of physiology in Prague, and Gabriel Valentin [1810-1883], a German physician and professor of physiology in Bern, CHE believed that these two neuronal elements could be located together, as in peripheral neuronal ganglia, but without a physical connection. When Robert Remak [1815-1865], a Polish/German embryologist, physiologist, and neurologist, demonstrated that nerve fibers and nerve cells were indeed connected, such cells were seen by him, and many of his peers, to be the suppliers of energy for the transmission of the nerve impulse from fiber to fiber. Purkinje and Valentin, however, while accepting Remak's connectivity results, retained vitalist thought by 
claiming that nerve cells were necessary for the circulation of fluid inside nerve fibers. In his dissertation on invertebrates, Hermann von Helmholtz [1821-1894], a German physicist/physiologist and former student of Müller, was particularly influential in his favoring of Remak's hypothesis. The question remained open about nerve-nerve cell connectivity in dorsal root ganglia until Louis Antoine Ranvier [1835-1922], the most prominent French histologist of the late 19th C, demonstrated clearly in 1875 anatomical connections between these "T- shaped" fibers and nerve cells in dorsal root ganglia (Ranvier, 1875; Barbara, 2007). He showed that one of the two branches of the axoncylinder was directed to the spinal cord, and the other to the periphery

It is generally accepted that cell theory was co-founded by three Germans; Matthias Jakob Schleiden [1804-1881], a botanist, Theodore Schwann [1819-1882], a physiologist, and Rudolph Ludwig Karl Virchow [1821-1902], a multitalented clinician (anthropology, pathology, ancient historian, biology) who is now recognized as "the father of modern pathology" (see Clarac and Barbara, 2011). Schwann's focus was on nerve cells and their associated cellular structures. He described the cell that bears his name and the myelin sheath of myelinated fibers. Later in the early 20th C, Ross Granville Harrison [1870-1959], an American biologist and anatomist, pioneered the use of cell cultures, including their role in the study of Schwann cells.

The anatomical relation between nerve cells and fibers was fully established by the mid-to-late 19th $\mathrm{C}$, but at that time most physiologists continued to think that nerve cells were of little importance for conduction of the nerve impulse (see section 2.4). This idea was shared by Augustus Volney Waller [1816-1870], a British neurophysiologist who was the first to demonstrate that nerve cells had a trophic effect on their axons (see below). It seems that the 19th $\mathrm{C}$ emphasis on a limited role for nerve cells prevented physiologists from considering their other roles such as the integration of their incoming impulses. Rather, neurons were thought at that time to simply be passive relay stations.

\section{3. "Neuron theory" followed by "MN theory"}

Neuron theory, the concept that each neuron in the CNS has an axon and other extrusions (later known to be dendrites) that made synaptic contact with other neurons and their extrusions, developed gradually throughout the 19th C (Barbara, 2010; Clarac and Barbara, 2011). Here we consider early work on the direction of nerve conduction and several properties of nerves, the latter merging with work on the all-or-none law, as studied in both nerve and muscle, and the NMJ, which requires consideration on the effects of curare at this critical site. At this juncture neuron theory merged with one of its offshoots, the "MN concept", this being the idea that this cell has properties of particular advantage for its control of muscle activation (Clarac and Barbara, 2011). Work on the MN concept was soon tied to the concept of MU, which is also reviewed below.

\subsection{Conduction direction and properties of nerves}

Novel experimentation had been undertaken by the mid 19th C: first on the direction of nerve conduction in the overall nervous system and then on measurement of the speed of conduction of the nerves supplying muscles. Next, relationships were explored between the intensity of nerve stimulation and its compound action potential response and between the strength of nerve and muscle stimulation and the force developed by the muscle so excited.

The experiments of the Edinburgh surgeon and physiologist Charles Bell [1774- 
1842] dealt largely with cranial nerves and the nerves of the spinal cord. $\mathrm{He}$ demonstrated the motor function of the trigeminal nerve of the horse and donkey as involved in mastication. In 1811, he undertook some vivisection experiments (which he disliked on ethical grounds) and demonstrated for the first time that the anterior (ventral) roots of the spinal cord had a motor function. François Magendie [1783-1855], a renowned French clinician, physiologist and founder of neuropharmacology, extended Bell's findings in work on puppies. It involved widely condemned and publicized painproducing vivisection. Magendie showed that the motor function of the anterior roots was matched by a sensory function of the posterior (dorsal) roots. Initially, he failed to mention Bell's earlier findings, thereby leading to a highly visible "ownership" controversy (Olmsted, 1944; see also Clarac and Barbara, 2011).

Helmholtz pioneered in the mid 19th $\mathrm{C}$ measurement of the speed of conduction of the nerve impulse, using a self-made pendulum myograph for measurements on the sciatic nerve of the frog (Fig. 3). He found this speed to be $\sim 25-45$ meters/second. 10 Helmholtz then made some measurements on human subjects, showing a faster conduction speed of $\sim 60$ meters/second. Among physiologists, these velocities created surprise because nervous activity seemed instantaneous. The significance of Helmholtz's measurements were initially better accepted and understood in the fields of psychology and psychophysics, where reaction time measurements were being pioneered by Wilhelm Wundt [1832-1920], a German clinician, psychologist, physiologist, and philosopher, who is known today as the father of experimental psychology.

\section{Figure 3 near here}

Another feature of nerve physiology that attracted attention in the late 19th and early 20th $C$ was the relationship between the intensity of multi-fiber nerve stimulation and the nerve's action potential responses (see 3.2 below). Similar experiments were undertaken on striated and heart muscle. Adolph Fick [1829-1901], a German physiologist, demonstrated that muscle contraction required a "threshold" intensity of stimulation, after which progressively stronger stimulation would reach a maximum after which even stronger stimulation had no effect. In 1871, Henry Bowditch [1840-1911], an American clinician, physiologist and later dean of the Harvard Medical School, worked in the Leipzig laboratory of Carl Ludwig [1816-1895], a renowned German physiologist and comparative anatomist. Bowditch demonstrated that "... An induction shock produces a contraction or fails to do so according to its strength; if it does so at all, it produces the greatest contraction that can be produced by any strength of stimulus in the condition of the muscle at the time." This was the first unambiguous demonstration of the all-or-none law. Its extension to skeletal muscle fibers and their nerve fibers came later (see below); using more advanced instrumentation that involved in succession the electrometer, string galvanometer, and thermionic valve amplifier ${ }^{\mathbf{1 1}}$

\subsection{Laws about nerve fiber excitation and muscle activation}

As neuron theory solidified in the late 19th and early 20 th $C$ it provided the fundamental functional rationale for conduction in nerve fibers, with the nerve impulse considered to travel from neuron to neuron by way of the axon of one neuron connecting with another neuron at "articulations," "interneuronic contacts," and "synapses." The depolarization wave traveling between neurons was known to be fast and thought to be possibly all-ornone but the latter required definitive proof. In 1902, Francis Gotch [1853-1913], a British neurophysiologist, used an electrometer to analyze the all-or-none law in multifiber nerves. He observed that the nerve's compound action potential increased in 
amplitude when the intensity of stimulation was increased. However, he also showed that the shape of this potential did not change from its threshold to its maximum response. Gotch concluded presciently that the stimulus-evoked increased amplitude of the potential was due to the progressive recruitment of a larger number of individual nerve fibers, with each individual one obeying the all-or-none law.

Keith Lucas [1879-1916], the leading British neurophysiologist of his time,12 was the first to demonstrate clearly that the all-or-none law was a property of skeletal muscle fibers (Fig. 4). His animal model was a nerve-muscle preparation of the frog's cutaneous dorsi muscle, which is comprised of $\sim 100-150$ muscle fibers, which Lucas reduced surgically to just a few (Lucas, 1905). This muscle is innervated by $9-10$ medullated nerve fibers. This small number, too, was exploited by Lucas (1909) in a subsequent article that came close to proving that the all-or-none law was also a property of nerve fibers. (Lucas, himself, emphasized the limitations of this study). The applicability of the all-or-none law to nerve fibers was shown clearly in a collaborative study by Edgar D. Adrian [1889-1977], the famed British neurophysiologist, a former trainee of Lucas, and a 1932 Nobel Laureate, and Yngve Zotterman [1898-1982], a pioneering Swedish neuroscientist. Their classic study (Adrian and Zotterman, 1926b) was one of the first to include extracellular recordings of the action potentials of single nerve fibers. This was made possible by the use of a recording device designed by Adrian (1926). It consisted of an electrometer combined with a three-valve amplifier, the latter based on the circuit described in Gasser and Newcomer (1921). ${ }^{\mathbf{1 3}}$

Figure 4 near here

An in-parallel issue at the turn of the 19th $C$ was the nature of the response of muscle and nerve fibers to repetitive stimuli of increasing frequency. Gotch and Burch (1899) were the first to study this issue, with tests undertaken on the frog sciatic nerve. More precise experiments on the frog sciatic nerve, however, were those of Adrian, which were undertaken in collaboration with his research mentor (Adrian and Lucas, 1912). 13 Among several original findings in this article, Alan Hodgkin [1914-1998], the famed British neuroscientist and 1963 Nobel Laureate, wrote that their use of the double-shock technique " ... showed that there are two kinds of summation (a) that in which the first stimulus is not strong enough to set up impulses but leaves behind a local excitatory effect which can sum with the second stimulus and, (b) that in which the first stimulus sets up a volley of nerve impulses whose propagation is blocked in a region of weakened conductivity, but which leaves behind a state of enhance conductivity that enables the second volley to get through." Interestingly Hodgkin (1979) went on to state that their paper " ... is beautifully written with many controls and ingenious experiments, but anyone reading it today is bound to part company with the authors at several points." One problem was that at that time the chemical nature of synaptic transmission was not known and this limited the ability of Lucas and Adrian to design experiments that could truly advance understanding of neuromuscular excitation and inhibition. In retrospect this was a great pity because in separate articles they had resolved the paradox of the so-called "Wedensky inhibition" exerted by nerve on muscle (Lucas 1911; Adrian, 1913), ${ }^{\mathbf{1 4}}$ which had generated a flurry of work and controversy after its initial presentation in 1885 by Nikolay Wedensky [1852-1922], a renowned Russian physiologist.

Lucas died prematurely and tragically during $\mathrm{WWI}$ in an airplane collision while developing navigational aids for aircraft, a part of his contribution to the war effort (Forbes, 1916; Fletcher, 1934). Adrian continued experiments, however, using the equipment of his mentor on his research topics until the end of WWI and for a few years thereafter. His illustrious "post-Lucas" career has been documented thoroughly by 
Hodgkin (1979).

\subsection{The neuromuscular junction (NMJ)}

We now step back in time to the mid 19th $\mathrm{C}$ in order to consider another aspect of $\mathrm{MN}$ theory: the relation between motor nerve fibers and muscle fibers as revealed at the NMJ. Valuable reviews of this topic, which extend to the present, are those of Howard (2003) and Swash (2008). Also homage should be paid to the 1942-1998 publications of René Couteaux [1909-1999], a premier French histologist and neurobiologist, who helped develop the modern concept of overall NMJ structure and function.

\subsubsection{Anatomical description}

The overall features of the NMJ were possibly first described by Louis Doyère [18111863] a French physiologist/zoologist in work on plantigrades (microscopic, waterdwelling, segmented invertebrates with eight legs) (1840). His findings were expanded by Charles Marie Benjamin Rouget [1824-1904], a French physiologist who remains well known for his correlation of physiology with microscopic anatomical structure, two German anatomists Wilhelm Krause [ 1833-1910], and Wilhelm Kühne [1837-1900], a German physiologist who coined the term "enzyme." Rouget (1862) described the junction in reptiles, birds and mammals and coined the term "end-plate," which was quickly changed to "motor end plate" by Krause (1863). Ranvier, too, was an active contributor on the structure of the NMJ in various animals (Fig. 5). Kühne (1887) focused largely on distinctions between the type of ending in mammals and reptiles vs. frogs, with it now known that the " ... distribution, size, and orientation of motor endplates is characteristic for each muscle and varies with each species" (Howard, 2003).

Figure 5 near here

Subsequent notable morphological advances included (1) the masterful use of the silver impregnation techniques by the Lithuanian-born, St. Petersburg histologist, Alexander Dogiel [1852-1922] (see Fokin, 2001), with " ... some of his illustrations almost resembling low power electron micrographs in their detail" (Swash, 2008), and (2) the much later first illustrations based on electron microscopyy (Palay and Palade 1955).

\subsubsection{The curare controversy}

A key aspect of early work on the NMJ was interpretation of the action of curare on the neuromuscular connection, which began before the above anatomical description. Claude Bernard [1838-1878], the famed French physiologist who is best known today for his work on the "milieu intérieur" (now known as "homeostasis"), made prominent the study of this drug. His curare work began about 1950 (see Bernard, 1857) as a logical extension of studies on toxic agents that had been undertaken by his mentor, Magendie, at the College de France. Bernard's goal was to discover the "intimate action" of curare: i.e., he wished to discover the action of curare using the tools of experimental physiology, rather than relying on anatomy alone. (He certainly wished to delineate the anatomical elements poisoned by curare but this was a secondary consideration). In a quite classical manner, Bernard's animal preparation was a frog with ligatures on a leg and other parts of the body for the physical separation of this leg's circulation from the remainder of the body's circulation while maintaining the test leg's normal innervation. He demonstrated that when this preparation was poisoned systemically by curare it exhibited normal sensorimotor activity in the test leg thus demonstrating that blood was the necessary carrier of the poison. In upper parts of the 
body where curare produced its paralytic effect on muscles, it seemed to Bernard that the poison killed the motor part of nerves and not their sensory part. This was shown by demonstrating movements of the test leg when stimulating upper parts of the body. In his 1858 "Leçons de Physiologie et Pathologie du Système Nerveux" ["Lectures on the Physiology and Pathology of the Nervous System"] Bernard described erroneously how "death" of the motor nerve proceeded from the periphery to nerve centers in the CNS, thereby drawing an inverse parallel with the process of Wallerian degeneration of a nerve fiber separated from its cell body. Bernard's belief that the action of curare was initially peripheral was based on the far earlier experiment of Felice Fontana [17301805] (1778), an Italian physicist, who showed that stimulation of a motor nerve could contract a muscle when it was immersed in a curare solution except for its most distal part.

Charles Edouard Brown-Séquard [1817-1894], a peripetatic Mauritian-born physiologist and neurologist, and Alfred Vulpian [1826-1887], a French neurologist, as well as some German physiologists, did not accept Bernard's belief in a retrograde action of curare. Just how was the action of curare brought about? A new set of recent findings made more likely another interpretation. Otto Funke [1828-1879], a German physiologist, du Bois-Reymond and others showed that the "action current" (also called the "electro-motive force," "electro-tonic force," or "negative variation") of a nerve was preserved in the presence of curare. Bernard, however, did not give much credence to electrophysiological measures, and he clung to the idea that a nerve could exhibit its normal, intact electrical sign while still being "killed" by curare. This line of thought came about because Bernard, like von Koelliker, defined the excitability of a nerve only as its capacity to contract a muscle.

The counter argument was based on the finding that curare did not affect the excitability of the motor nerve since not only was its electrical sign preserved, but also its ability to contract a muscle was preserved when its most distal part remained free of curare. Accordingly, Alfred Vulpian [1826-1887], a French neurologist, wrote that curare must block the "... transmission of the nervous excitation to the muscular fiber" (Vulpian, 1883). This clear-cut difference in interpretation between Bernard and Vulpian came about because Vulpian understood the distinction between a "function" and a "property." Also he had a far greater appreciation of the emerging value of electrophysiology than did Bernard. Furthermore, Vulpian's reasoning, like that of Funke, was also based on the recent discovery of a new histological structure, the motor end plate, as described above.

Bernard remained stubborn about his curare hypothesis because of his observation that during the slow poisoning of a frog with a low dose of curare, spontaneous movements were blocked, but the electrical stimulation of a motor nerve could still contract a muscle for at least a little while. This result does not surprise to us today because a large release of acetylcholine can displace a low concentration of curare in the synaptic cleft. Bernard inferred that curare first uncoupled the motor nerve from the spinal cord (his "décrochement du nerf moteur"). He continued to promulgate the idea that the blocking of neuromuscular transmission was not located between the motor nerve and the muscle, but between the nerve and its center in the CNS. This idea became so attractive to him that he disclaimed his initial idea of the blocking effect of curare traveling from the periphery to the CNS, and adopted the inverse idea in his 1864 lecture. This erroneous idea is almost impossible for us to understand today unless the evolution of Bernard's incorrect reasoning is understood. 
3.3.2. Subsequent developments:"soup" vs. "sparks"

An inciteful review of the chemical vs. electrical ("soup" vs. "sparks") transmission controversy for the NMJ and CNS synapes was written by Harry Grundfest [1904-1983] (1957), an influential American neurophysiologist (Cook, 1986). He emphasized that when " ... the systematic study of electrophysiology was established in the 1840s and 1850s by du Bois-Reymond and Helmholtz ... Neuromuscular transmission was taken for granted." For example, Kuhne (1888) was attracted to the possibility that " ... a nerve only throws a muscle into contraction by means of its currents of action", albeit he never proved his assumption. Before this, however, du Bois-Reymond (1874) had delineated the difficulties involved in proving that the transmission was electrical, albeit he favored this possibility. He emphasized presciently that only one other alternative was possible, electrically activated secretion from the nerve ending of an excitatory substance, "ammonia, lactic acid, or some other substance." To explain electrical transmission (albeit not necessarily support it, as is commonly supposed), du BoisReymond (1874) provided sketches of lines of current flow that were quite similar to those provided by Eccles (1946) in his last major attempt to champion electrical transmission. Almost seventy years after the du Bois-Reymond reflections, Eccles (1953) conceded chemical transmission at the NMJ. Doubt remained, however, as exemplified by a champion of chemical transmission, Wilhelm Feldberg [1900-1993], a prominent German-born British physiologist and pharmacologist, who wrote a year later that " ... we cannot state with certainty whether the transmission is chemical or electrical" (Feldberg, 1954). It took the efforts of three remarkable investigators to lay the issue to rest and subsequently be co-awarded a 1970 Nobel Prize " for their discoveries concerning the humoral transmittors in the nerve terminals and the mechanism for their storage, release and inactivation." These three were Ulf von Euler [1905-1983], a Swedish physiologist and pharmacologist, Julius Axelrod [1912-2004], an American biochemist, and Bernard Katz [1911-2003], a German-born British biophysicist. As well summarized by Rubin (2007): "Due to the combined achievements of von Euler, Axelrod, and Katz, the scientific establishment finally embraced without equivocation the concept of chemical transmission of nerve impulses, and the discredited theory of electrical excitation finally faded from the scene. Moreover, because of their work, not only were the basic neurotransmitters of the adrenergic and cholinergic nervous systems finally identified, but von Euler, Axelrod, and Katz also helped in a major way to elucidate the processes involved with the biosynthesis, release, actions, and inactivation of neurotransmitters. These convergent findings incalculably enriched our fundamental understanding of a basic neurochemical process."

The 1957 Grundfest review paid tribute to the post-1880 key players in the development of ideas on the NMJ, which included so many outstanding neuroscientists. It has become conventional to focus discussion of "soup" vs. "sparks" on the three key mid-20th C protagonists, Eccles and his "opponents," Henry Dale [1875-1968], a British pharmacologist, and his counterpart in Germany, Otto Loewi [1873-1961]. The latter two were awarded a 1936 Nobel Prize for their work on chemical transmission. Eccles, Dale, and Loewi had impressive predecessors and collaborators, however, whose substantial contributions to the NMJ transmission controversy created much interest and excitement in the ever continuing unraveling of nerve-muscle relations. 19 


\subsection{The concept of the motor unit (MU)}

This concept, that each MN supplies its "own" group of muscle fibers, was formally introduced in 1925 by the British physiologist, Edward Liddell [1895-1981], and his mentor, Sherrington, albeit with two important precedents (see Duchateau and Enoka, 2011). This and its companion article (Sherrington, 1925) was a milestone in neuroscience and it resulted in large part for a 1932 Nobel Prize being awarded to Sherrington. Once introduced, several lines of work then began on MUs, with two focused upon in this brief review. First, it became necessary to relate the MU concept to what was known about different types of muscles and their fibers. The early history of this field was described expertly by the distinguished British biochemist, Dorothy May Needham [1896-1987] (1926; see also Smith, 1961) and only the highlights are presented here. Ranvier $(1873,1874)$ was probably the first to compare the properties of "red" muscles, used for sustained, low-force contractions, and "white" muscles, used largely for short-lasting, more powerful contractions. By 1925, when the MU concept was introduced, much work had been undertaken on the properties of such muscle's constituent fibers in a wide variety of invertebrate and vertebrate species. The prevailing view was that across species, red muscles were composed largely of one fiber type, whereas white muscles were composed of two fiber types, both red and much uncertainty about their detailed composition. The challenge was then to relate these findings to the MU concept. This field of inquiry was reviewed masterfully by the American neuroscientist, Robert Burke (1981). Much of the critical work was not undertaken until the 1960s-1970s, with work from Burke's own group on the forefront (e.g., Fig. 7). Since then it has been generally accepted that across species in several invertebrates and most vertebrates, including possibly humans (albeit with some dissent), there are three types of MU: FF with high threshold MNs supplying type FG (also termed Ila) muscle fibers with fast contraction rate, high force development, and anaerobic (glycolytic) metabolism; FR with MNs of slightly lower threshold supplying type FOG (Ilb) fibers of similar contraction rate, lower force, and both glycolytic and oxidative metabolism; and S (I) with low threshold MNs, supplying SO fibers with slow contraction rate, the lowest force, and oxidative metabolism. In general, white muscles are composed largely of type FF and FR MUs and red muscles largely of $S$ units.

\section{Figure 7 near here}

In subsequent years and up to the present, with molecular genetics adding much to what is known about the properties of all the components of MUs, work continues to appear that reinforces the MU concept that (1) MN properties are closely tied to the properties of their muscle fibers, and (2) a muscle's MU properties are closely tied to the muscle's role in posture and movement, with type $S$ units used in posture and sustained contactions of limited forcefulness, FR units in more forceful sustained movements, and FF units in explosive, short-sustained movements.

It is conceded by most inverstigators that $\mathrm{MN}, \mathrm{MU}$, and muscle fiber typing are all approximations, with individual properties existing along a continuum and the combined properties bringing out the concept of types. Furthermore, new evidence continues to emerge, including the value of considering three rather than two fast fiber types (IIX between Ila and IIB; Schiafino and Reggiani, 1996), which match to the properties of their innervating MNs (Chakkalakal et al., 2010).

A second line of study about MUs also began well before the concept came into full being in 1925. This was the innervation ratio; the number of muscle fibers innervated 
by a single MN. Remarkably this work began well before even neuron theory, let alone MN theory, was accepted universally! This was a study by Karl Bogislaus Reichert [1811-1883] (1851), a German anatomist, former student of Müller, and influential contributor to cell theory. He reported a ratio of one nerve fiber to 20-30 muscle fibers in the sterno-cutaneous muscle of the frog. There were many further such studies in the late 19th $C$ and considerable interest in this topic after 1925, including a study by John Eccles [1903-1997], an Australian-born 1963 Nobel Laureate (for his contributions, see Stuart and Zigmond (2006), and his mentor, Sherrington (1930). Another valuable study undertaken in Sherrington's laboratory was the sole biomedical article of D.A. Clark (1931), which included a valuable history of such work back to Reichert (1851).

In Burke's (1981) review two points are emphasized about motor unit innervation ratios in the cat. First, the ratio tends to be " ... larger in large limb muscles (e.g., 600$1,700 \ldots) \quad \ldots$ smaller in intrinsic hand muscles $(100-340 \ldots$ ) and very small in extraocular muscle (13-20 ...)." Second, innervation ratios are highest in type FF units, lower in type FR units, and lowest in type $S$ units. Again these data have functional implications for the MU concept.

\section{Trophic aspects of nerve-muscle relations}

In this section we focus largely upon the mammalian literature while emphasizing that virtually all aspects of CNS and nerve-muscle plasticity are far more readily accomplished in invertebrates and non-mammalian vertebrates (for review, see Wiersma, 1967; Salpeter, 1987, Clarac and Pearlstein, 2007).

It has been known since antiquity that section of a motor nerve in mammals (including the human) paralyzes the muscle it innervates and leads to muscle wasting (denervation atrophy). It is only in quite recent years, however, that it was shown that muscles have a trophic influence on the MNs that innervate them. What follows are the highlights of research on nerve-to-muscle and muscle-to-nerve trophism. Since the 19th C, such work required consideration of the detailed structure of MNs, the NMJ, and muscle fibers. Since the early 19th $\mathrm{C}$ this work has taken advantage of progressively more powerful techniques. For the relatively current state-of-the-play see, for example, Vrobova et al. (1995) for the overall issues, Kernell (2006) for MNs, Molgó et al. (2009) for the NMJ, and Maclntosh et al. (2006) for striated muscle. In addition, since WWII the literature on trophism has expanded dramatically and it now emphasizes molecular details (see, e.g., Chakkakalal et al., 2010; Hirokawa et al., 2010).

\subsection{Lesions in peripheral nerves}

Until the second half of the 20th $\mathrm{C}$, experiments using experimental lesioning of nerves and regeneration failed. For wounds that included nerves, surgeons always focused largely on cleaning and removing tumors and bone parts in the damaged region. Even in antiquity, however, surgeons tried to suture nerves and induce regeneration. Paul of Aegina [ 625- 690], a Greek physician best known for writing a medical encyclopedia, observed sectioned nerves sticking to their surrounding tissues. In keeping with an idea of Galen, Roger of Salerno [<1140- 1195], an Italian surgeon and medical writer, tried to repair nerves by encasing them in egg white. Guy de Chauliac [1298-1368], a French surgeon who wrote an influential 1363 treatise on surgery, "La Grande Chirurgie" ["The Great Surgery"], made several recommendations: "The first one is to suture right in the flesh if no matter is lost; the second requires to insert a drain in the lowest part of the wound; the third is to pour sedative drugs on the nerves where they 
are cut; the fourth is to bandage over the wound a compress of soft wool." He treated a lesion in a nerve of King Charles IX in France with warm oil, turpentine, and brandy applied to the wound. These procedures lead to no success as pointed out by Daniel Delaroche [1743-1813] (1778), a Swiss-born clinician in Paris who focused on nervous diseases, wrote that nerves "... lose forever their power to transmit movement between the parts separated by the wound, although they can be put together for healing"

William Cumberland Cruikshank [1745-1800] was a British anatomist/chemist and an anatomical prosector/assistant of William Hunter [1718-1783], a famed Scottish anatomist and obstetrician. Cruikshank undertook many famous experiments on the regeneration of nerves. For example, he reported sprouting of the vagus nerves after their bilateral section in the dog. The regeneration work of Cruikshank was inspired by Willis, who had discovered the lethal effect of bilateral section of these nerves at the level of the neck, whereas section of only one of them had little effect. In the former case, the animal did not breathe properly, inflammation of the eyes was observed, and there was vomiting with large amounts of associated saliva before death. Such an animal preparation can be seen today at Hunterian Museum, London, GBR. Fontana (1778) and Bernard (1847) showed later that sprouting was possible in a unilateral vagus nerve of the rabbit but only on one side. Animals died after transection on the other side, with the exact reason not known at the time of his study.

\subsection{Nerve degeneration and regeneration}

In 1850, Waller, who lived and worked largely in several West European countries, described the degeneration named after him, "Wallerian degeneration." Previously, anatomical deficits after the section of a nerve had been described in three German articles; those by Hermann Nasse [1807-1892] (1839), Augustus Fridericus Guenther [1806-1871] and Matthias Johann Albrecht Schoen [1800-1870] (1840), and Hermann Friedrich Stannius [1808-1883] (1847) (Stannius, 1837). However, the work of Waller was by far the most complete and thorough (e.g., Fig. 6). THIS ADDITION IS FINE

Figure 6 near here

One of Waller's best-known studies involved him making a section of the nerve innervating taste buds (the glossopharyngeal nerve) in the tongue of the frog. A few days after section, the transparency of the tongue's muscle fibers permitted the observation under the light microscope of degenerating distal nerve fibers. They were shown to lose their tubular shape, with spherical myelin globules from the myelin sheaths appearing all along the fibers distal to their transection. The appearance of this disintegration was called "the first law of Waller," which emphasized the necessity for fibers to be connected to their cell body. Accordingly, the method to obtain Wallerian degeneration was called the "neurotropic (or "neurotrophic") method". It permitted the anatomical tracing of the physical continuity between nerve fibers and their cell bodies. The French Academy of Science rewarded this discovery by awarding the Monthyon Prize to Waller in 1856. The second law of Waller made explicit that the cell body represented a "trophic center" necessary to preserve nerve fibers. This law led to Waller being awarded the Medal of the Royal Society of London in 1860. Waller concluded in his 1851 report that " ... the cell bodies of the dorsal root ganglia have a trophic action necessary for sensory fibers to have their proper shape and function ..." It was shown much later shown that macrophages and Schwann cells digest degenerating axons and their myelin sheath, with a subsequent atrophy of the innervated muscle fibers. During regeneration, the sprouting of nerve fibers occurs in the former neural tubes and reaches the previous dennervated muscle, and begins to reinnervate it (see for 
example, Ramón y Cajal, 1928). Among peripheral degeneration processes seen in the clinic, "névrite segmentaire péri-axile" ["peri-axonal segmental neuritis"] was one of the first to be described, this being by Albert Gombault [1844-1904], a French neurologist and former student and then collaborator of Charcot. They described this deficit in a case of lead poisoning (also called "plumbism," "saturnism," or "painters colic") (Charcot and Gombault, 1981). ${ }^{15}$

Sprouting processes were studied in detail by Santiago Ramón y Cajal [1852-1934], the famed Spanish neurohistologist and 1906 Nobel Laureate (hereafter called Cajal). He was one of the first to describe the growth cone: i.e., each growing neurite ends with a small extending bud, which is now known to act as a guide. Several drawings of Cajal show sprouting growth cones during regeneration. He thought that these structures sensed mechanical and chemical properties of the environment (Ramón y Cajal, 1928).

Peripheral regeneration occurs in mammalian nerves, albeit not with full success as has been emphasized since the early 19th C (see, e.g., Langley, 1918; Ramón y Cajal, 1928) and then with more detail by the WWII era (e.g., Sperry, 1945). There is very scant evidence of such regeneration in the mammalian CNS albeit barriers to the process are gradually being eliminated. A "hybrid" approach to such regeneration created interest three decades ago when David and Aguayo (1981) developed in the spinal rat an external "bridge" composed of a peripheral nerve segment inserted into the medulla and the spinal cord distal to the transection. New axons with cell bodies at both ends of the bridge grew within the nerve segment for a distance up to 30 millimeters but only a very short distance $(\sim 2 \mathrm{~mm})$ after re-entering the CNS at its opposite end. This study illustrated the supportive environment for regenerating axons in the peripheral nerve segment and the opposite in the CNS. The technique has not led to a major clinical advance, however.

\subsection{Crossed regeneration between different muscles}

In order to better understand how MNs and muscles interact with one another, a widespread experimental paradigm from the 20th $C$ onwards has been to note the effects of cross regenerating nerves to muscles other than their own. The American neuropsychologist/neurobiologist and a 1981 Nobel Laureate, Roger Sperry [19131994] (1945) provided a valuable review of the early literature. In commenting on a remarkable study by the French physiologist and one of the founders of modern experimental brain science, Marie-Jean-Pierre Flourens [1794-1867], Sperry wrote " ... It is generally agreed that the first attempt to study the results of crossing nerves was made by Flourens (1828). In a cock, he cut and crossed the two main nerves leading from the brachial plexus to the ventral and dorsal aspects of the wing, respectively, and reported that after a few months the bird recovered use of the wing so that it could fly as well as before." Flourens emphasized that this study had several technical flaws. There was then a hiatus of over 50 years before serious work began again in the $1880 \mathrm{~s}$ and 1890s on the cross regeneration problem. It seems likely that among the plethora of clinical and experimental studies that then followed up to mid 20th C, the most convincing experimentally based evidence of reasonably successful cross reinnervation was obtained by Osborne and Klivington (1910), a leading Czech neuroscientist, Ernest Gutmann [1910-1977] while working at Oxford (see, e.g., Gutmann, 1942) and Sperry $(1941,1947)$. From their efforts, which were subject to a certain degree of self- and peer-imposed criticism, we can jump to contributions made by Eccles in his Canberra, AUS laboratory in the late 1950s. By that time it was well known and accepted that 
mammalian limb muscles were slow contracting at birth and then differentiated within a month into slow- and fast contracting types. It had also been shown by the Eccles' and other groups that some MN properties (e.g., hyperpolarization; firing rate behavior) were appropriate for the contractile properties of the muscle they innervated.

The first Eccles' muscle differentiation study was undertaken on cats from one day of birth to the adult. The goal was to determine if the matching process was induced by the muscle, or by its MNs, or both. Their results, which were not based on cross-union experiments, favored indirectly the role of innervation, including the observation that slow-contracting muscle properties were particularly subject to neural influences (Buller et al., 1960a). The second study was a more definitive one involving testing the effect of crossed innervation of a fast and a slow muscle on the speed of their contraction. It was shown that the fast MNs could speed up slow muscles and vice-versa albeit the transformations were not complete. The transformations were reduced when $\mathrm{MN}$ discharge was reduced (by spinal transection) and abolished when MN discharge was abolished (by spinal transection plus deafferentation). These results emphasized the mutability of muscle fibers in the adult animal and, as reviewed by Pette (2001) they led to increased interest in confirming and extending "the notion of muscle plasticity." Such studies " ... demonstrated that MN-specific impulse patterns, neuromuscular activity, and mechanical loading play important roles in both the maintenance and transition of muscle fiber phenotypes. Depending on the type, intensity, and duration of changes in any of these factors, muscle fibers adjust their phenotype to meet the altered functional demands. Fiber-type transitions resulting from multiple qualitative and quantitative changes in gene expression occur sequentially in a regular order within a spectrum of pure and hybrid fiber types."16

A particularly noteworthy aspect of the Buller et al. (1960b) report was their reasoning on just what caused the transitions produced in their cross-innervation muscles. Even though they showed the necessity of MN discharge they nonetheless concluded that: " ... the neural influence on muscle speed is not exerted by nerve impulses as such. It is postulated that a substance passes down the axons of slow motoneurones, crosses the NMJs and traverses the muscle fibres, transforming them into slow contracting units and maintaining them so. Possibly there is also a substance from fast motoneurones that acts via a comparable pathway to accelerate muscle contraction." This postulate created instant excitement in the field of nerve-to-muscle trophism, 17 which continues to this day (see, e.g, Chakkalal et al., 2010).

Work on cross regeneration continued in many laboratories until the 1980s but it then became out of favour due to difficulties encountered in characterizing further the molecular changes in the multitude of cross-union muscles and in interpreting so many diverse results from so many laboratories.

\subsection{Muscle to nerve trophism}

The possibility of muscle-to-nerve trophism was first suggested by Franz Nissl [18601919] (1892), a German considered the best neuropathologist of his day. He removed the facial nerve in rabbits and used a light microscope to study changes in neurons of the facial nucleus. His report emphasized major alterations in their granular material that became later known as Nissl substance and even later found to consist of RNA. Fig. 8 includes a summary of Nissl's classic findings, which are summarized in a valuable monograph by McComas (1978), a British/Canadian neurologist. 
Subsequent to Nissl's 1892 study, there was little research on muscle-to-nerve trophism for several decades. As reviewed by McComas, some of the more prominent work up to the late 1970s on the spinal responses to axotomy included documenting changes in (1) the glial cells that abut on MNs, (2) biochemical events within MNs, (3) intracellularly recorded $\mathrm{MN}$ properties, (4) the above after successful re-innervation was achieved. McComas also reviewed the beginning research on axoplasmic flow from muscle-to-nerve, which was pioneered to some extent by Watson (1967) and Kristensson and Olsson (1971). Their reports emphasize, however, the iterative nature of such research, which began with demonstration of such flow in the opposite direction (Weiss and Hislop, 1948). 17

The next major step in muscle-to nerve trophism was demonstration of changes in MN properties following the chronic stimulation of muscle, and muscle inactivity and stretch. Key articles in this area were those of Czeh et al. (1978), Gallego et al. (1979) and Munson et al. (1997). This work proceeded more-or-less in parallel with that on the nature of trophic substances that muscle might send to their innervating MNs. The latter field of endeavour is commonly said to have been inspired by the first description of "nerve growth factor" (Levi-Montalcini, 1952), $\mathbf{1 8}$ which was first shown to be required for the growth and maintenance of sympathetic and sensory neurons (see also LeviMontalcini, 1987). As work on such factors flourished in many laboratories, a "brainderived neurotrophic factor (BDNF)" was identified (Barde et al., 1982), characterized as a polypeptide, and then shown to also exist in muscle fibers (Funakoshi et al., 1993; Koliatsus et al. 1993). This led, in turn to the characterization of two other muscle factors, NT-3 and NT-4/5, with all three now known to participate in muscle-to-nerve trophism, as shown in Fig. 9. These developments concerning neurotrophins, neurotrophin receptors, and polypeptides are reviewed briefly in Macintosh et al. (2006) and the number of such factors shown to participate in nerve-to-muscle trophism continues to expand (see, e.g, Table 1 in Hirokawa et al., 2010) (Fig. 9).

Figure 9 near here

\section{Concluding thoughts for what follows}

This historical presentation has shown that the relations between nerves and muscles have intrigued clinicians and investigators since antiquity. The topic has been addressed by leading thinkers from at least Hippocrates onward. In the modern era, this article has mentioned the contributions of 13 Nobel Laureates giving substance to our view that the brain's control of movement has always been on the forefront of the ever-expanding field of neuroscience.

The next three articles provide more specialized historical information. First, in Clarac and Barbara (2011) the emphasis is on the 19th $C$ and the first part of the 20th $\mathrm{C}$, as the concept emerged from histology, neurology, and physiology that a nerve cell that came to be known as the MN controlled posture and movement. Next, the article of Duchateau and Enoka (2011) reviews the advances that accured once the concept of the MU was introduced and it became possible to record their behaviour using extracellular recording techniques. Stuart and Brownstone (2011) then review the advent of intracellular recording in $\mathrm{MNs}$ and their adjacent interneurons and the advances that quicky ensued. 
Finally, Brownstone and Stuart (2011) takes us from the present, when the powerful techniques of truly modern biology are in sway, to future possibilities for advancing $\mathrm{MN}$ neurobiology by achieving a full integration of molecular approaches with those of cellular and systems neuroscience. Clearly, much has been learned about MNs in the past and new vistas continue to emerge for future discoveries about this intensively studied and still fascinating neuron.

\section{Footnotes}

1The term muscle "contraction" appeared in the literature many centuries ago. For example, the term was used by the renowned Roman physician of Greek ethnicity, Claudius Galenus (Galen) [130-200] from Pergamum (now Bergama, TUR) (see Galen, 1556) and a century later by Francis Glisson [1597-1677], a British physician, physicist, and anatomist, in his 1672 book "Tractatus de natura substantiae energetica" ["Treatise on the energetic nature of substance"]. Following the largely post-WWII findings on the similarities and differences between shortening, isometric, and lengthening contractions, the term "muscle "activation" is usually more accurate than muscle contraction. Its use remains disappointingly limited, however.

2The "Theory of Humors," which was accepted by Hippocrates and all the Greek and Roman physicians of that time, was that the human body was under the control of four solutions (humors): black bile (Gr., melan chole), yellow bile (Gr., chole), phlegm (Gr., phlegma), and blood (Lat. sanguis). These solutions were thought to be in equilibrium in healthy subjects but depending of the relative percentage of their presence, it could explain different moods and personalities (e.g., melancholic, phlegmatic, etc.). Illness was believed to be due to a desiquilibrium between these substances. This explained why bloodletting was so popular and often the sole practice to cure patients to restore the equilibrium between humors.

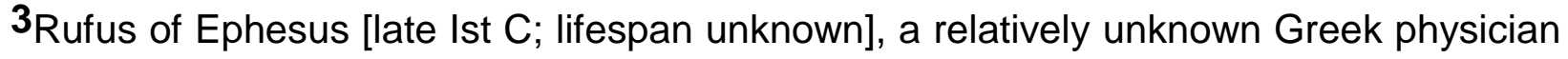
of the late 1st and early 2nd C, was "rediscovered" to some extent in the 19th C. Contrary to Aristotle, he made a precise distinction between nervous "white bundles" and the "white bundles" of tendons: "Among the nerves coming from the brain and the spinal cord, some active (motor) or sensory are voluntary, the others surrounding joints are ligaments. The thick bundles extending from the neck and those extending from the soleus-gastrocnemius muscles to the Achilles heel are called tendons" $\mathbf{4}$ (Daremberg, 1854).

${ }^{4}$ All translations are by J-G.B. and F.C. except otherwise noted.

5 In his treatise, "De Pictura" ["On Painting] (1435), the multi-talented Italian architect, philosopher, and poet, Leon Battista Alberti [1404-1472], recommended that young painters should study human muscular organization, which was usually shown at that time in the form of an "écorché" (an animal or human after its skinning). The "écorchéists" were artists, anatomists, and mathematicians, including da Vinci and Michelangelo di Lodovico Buonarroti Simoni [1475-1674], these two having many additional talents. Possibly, the most famous écorché was the 1767 one created by the French sculptor. Albrecht Dürer [1471-1528], a German painter, printmaker, and theorist considered the greatest artist of the "Northern Renaissance." He described the different proportions of 
the static and dynamic human body. In 1528 he published "Vier Bücher von Menschlicher Proportion" ["Human Proportions"], which consisted of four books in which he presented the different proportions of the human body and their changes during movement. At the end of this book he appended an essay on aesthetics in which he presented his thoughts on how an artist builds on personal visual experiences to create a beautiful painting.

6Harvey graduated in 1597 with a BA in Arts from Caius College, University of Cambrige, GBR. He then traveled through France, Germany and Italy, where he entered the University of Padua. There, he developed a relationship with Girolamo Fabrici d'Acquapendente [1533-1619], a pioneering anatomist and surgeon known today as the father of embryology. In 1602, Harvey graduated with an MD at the age of 24 years from the University of Padua. In 1628 he published "De Motu Cordis" ["On the Motion of the Heart and Blood"] in which he was the first to describe the two circulations emanating from the heart: that from the left ventricule suppling the entire body and that from the right ventricule for the pulmonary circulation.

7 Von Haller believed that motor nerves were filled with liquid: "Therefore, upon the whole, it seems to be certain, that, from the vessels of the cortex, a liquor is separated into the hollow pipes of the medulla, which are continued with the small tubes of the nerves, even their soft pulpy extremities, so as to be the cause both of sense and motion. But there will be a twofold motion in that humor; the one slow and constant, from the heart; the other not continual, but exceedingly swift, which is excerpted either by sense or any other cause of motion arising in the brain" (von Haller, 1786/1966).

8Prochaska introduced the concept of "vis nervosa," a latent nervous force possessed in nerves, as a direct analogy of the "vis gravitans" [force of gravity] of Isaac Newton [1643-1727], the renowned British physicist. Prochaska believed that his vis nervosa provided the energy necessary for reflex actions. He also revised the centuries old concept of sensorium commune to make it the CNS site of interaction between sensory input and motor output. He emphasized that the site included the spinal cord, medulla oblongata, and basal ganglia, and as such, was independent of consciousness.

9The Dutch microscopist known today as the father of microbiology, Antonie van Leeuwenhoek [1632-1723], sent numerous letters to the Royal Society of London. In a 1717 one he described a section made in the large optic nerve of an ox. He could see small circular elements surrounded by a sheath. Shortly after making the section, the fibers displayed a flattened appearance, which he interpreted as the disappearance of an internal liquid, as based on his belief in the doctrine that nerves contain a fluid. Felice Fontana [1730-1805], an Italian physiologist and natural scientist, also observed nerves with a microscope and suggested that the animal spirits traveling inside nerves were made of particles that he thought he could see. Christian Gottfried Ehrenberg [1795-1876], a highly productive German zoologist, comparative anatomist and microscopist, made similar observations and distinguished between narrow and enlarged nerve fibers. In sharp contrast to the above, Remak debunked the idea that nerves contained animal spirits. Contrary also to Müller, Remak argued that nerve fibers were made of solid gelatinous matter with a fine fibrillar structure. Purkinje favored this interpretation and coined the term "axon-cylinder" for thin fibers. Others, however, clung to the idea that nerves were filled with a liquid. This group included well-known, highly respected scientists, including Gabriel Gustav Valentin [1810-1883], a German- 
born professor of physiology in Bern, CHE, and Jakob Friederich Henle [1809-1885], a German physician, pathologist, and anatomist, who contributed much to modern medicine.

10The recording technique used by Helmoltz was inspired by the method of Claude Pouillet [1790-1868], a French applied physicist who developed in 1844 a method to track projectiles. Helmholtz undertook his work in Berlin from where he submitted a note to the Comptes Rendus de l'Académie des Sciences in 1850: "I found it was not too difficult to evaluate the time interval for the nerve impulse to travel from the plexus of the sciatic nerve to the gastrocnemius of a frog ... The length between the two excited points of the nerve being 50 to 60 millimeters, it took 0.0014 to 0.0020 seconds (60 millimeters traveled in 0.0014 seconds would be at approximately 43 meters per second; 50 millimeters in 0.0020 seconds, 25 meters per second) for the nerve impulse to travel this distance." These measurements were further refined by Étienne-Jules Marey [1830-1904], the renowned French physiologist and co-father of cinematography, du Bois-Reymond and Frans Cornelius Donders [1818-1889], the Dutch physiologist who was a co-founder of the science of opthalmology.

11Jonas Ferdinand Gabriel Lippmann [1845-1921], a Franco-Luxembourgish physicist, invented the capillary electrometer in 1872. (He was awarded a Nobel Prize in 1908 for pioneering color photography). Lippman's electrometer could indeed measure minute electromotive sources and its use quickly became popular and widespread. It was difficult to manipulate, however, and several improvements were soon proposed. The best was that of Willem Einthoven [1860-1927], a Dutch clinician and physiologist, this being a string galvanometer, the electromagnetic theory of which he presented at the first Congress of Physiological Sciences held in Basel, CHE in 1889. Beginning later in 1901, Einthoven progressively improved his string galvanometer to the extent that by 1903 it was the key component in the first truly practical electrocardiography machine, for which invention he was awarded a Nobel Prize in 1924. The next advance was to the thermionic valve amplifier, the first instrument to enable the extracllular recording of the action potentials of single nerve and skeletal muscle fibers.

12The following quote is noteworthy: "In the death of Keith Lucas on October 5, 1916, physiology suffered the loss of a really great investigator. At thirty-seven years of age he and his junior co-workers had already, as I see it, thrown more light on the fundamental functional properties of the excitable tissues, nerve and muscle, than has been shown by the combined efforts of all other investigators; and the possibilities of future achievement, had he lived, are altogether incalculable" (Forbes, 1916).

13 Both the all-or-none law and the devices for recording the action potentials of single nerve fibers were developed iteratively such that it is difficult to state with certainty just who were the original pioneers. The early history of the all-or-none law for collations of nerve fibers was summarized many times, including in Adrian (1914a) and Adrian and Forbes (1922). Definitive proof, however, required analysis of the discharge properties of single nerve fibers. Such recordings in a single sensory fiber were possibly first obtained by Adrian (1926), this being more definitive in Adrian and Zotterman (1926a). The early history of recording devices for measurement of the action potentials of single nerve axons has also been reviewed many times. Some interesting examples over the years include Forbes and Thacher (1920), Frank (1986), and Schoenfeld (2002). It deserves emphasis that Alexander Forbes [1882-1965] was an American 
neurophysiologist who pioneered with Catherine Thacher [1901-1975] the use of a vacuum tube amplifier in neurophysiological experiments. He was also a leading thinker about the possibility of an interaction between electrical and chemical transmission at CNS synapses (see, e.g., Forbes, 1939; Marcum, 2006).

${ }^{14}$ Adrian provided a succinct summary on the nature of Wedensky inhibition based on his (1913) and Lucas's (1911) study of the phenomenon: "Wedensky's observation that a series of strong stimuli may produce inhibition whilst a series of weak stimuli of the same frequency produces a continued tetanus is to be explained by the fact that strong stimulus can excite the nerve at an early stage of recovery before a summated contraction can be produced. The disturbance set up in the nerve will be followed by a refractory period, which will cut down the size of a succeeding disturbance. Thus a series of strong, stimuli will set up a series of small disturbances none of which will reach the muscle. A weak stimulus has no effect on the nerve until a more advanced stage of recovery has been reached and then the stimulus cannot avoid affecting the muscle as well as the nerve. Thus a series of weak stimuli cannot produce inhibition. This agrees in all respects with the explanation advanced by Lucas."

15Gombault was an astute clinician as well as an experimentalist. With Charcot, he studied lead poisoning in guinea pigs that had been fed for six months with food containing lead. While there were no clear behavioral disturbances, they found that most nerve fibers showed marked defects of myelin. Using the teasing method, they dissociated the nervous trunks of the brachial plexus and sciatic nerve. The axons remained intact but the Schwann cell sheaths were severely affected. Some of these lesions recovered to some extent if lead ingestion was discontinued (Charcot and Gombault, 1881). Subsequently, Gombault demonstrated similar lesions in humans with lead poisoning. His pictures were reproduced in Greenfield's widely read "Neuropathology," up to the 1976 (3rd) edition.

16The data obtained by Drubowitz (1967) demonstrated the histochemical modifications induced by cross union of the nerves to soleus and FHL in the kitten, and the adult cat and rabbit. This procedure produced a dramatic change in the histochemical pattern of fast muscles, with the development of areas of muscle fibers indistinguishable from the fibers of the normal soleus muscle. The converse change from the histochemical pattern of slow soleus to that of fast muscle has been less consistent. Normally soleus is rich in enzymes like succinate dehydrogenase and nicotinamide-adenine dinucleotide $(\mathrm{NADH} 2)$ diaphorase and poor in phosphorylase and myosin adenosine triphosphatase (ATPase). Fast muscles have opposite enzyme contents. In cross-innervated FHL, fast muscle fibers become rich in $\mathrm{NADH} 2$. It is now quite well known that the neural influences determining the contractile properties of fast and slow muscle also have a profound controlling influence on the structure and metabolic activity of these muscles' fibers.

17The field of nerve-to-muscle trophism owes much to the first (1948) description of slow axonal transport by Paul Weiss [1898-1989], an Austrian-born premier biologist whose seminal contributions in the fields of growth, differentiation, and neurobiology were made in both AUT (1922-1931) and the USA (post 1931). (His 1948 co-author was Helen B. Hiscoe, an American natural scientist, who wrote a well-known historical novel entitled "Appalachian Passage"). Over two decades later Bernice Grafstein (1949), an American neuroscientist, reviewed subsequent work on axonal transport, 
which included examples of both slow and fast transport. The subsequent progress on the molecular mechanisms of axonal transport (Hirokawa et al., 2010) has been explosive.

18 Rita Levi-Montacini is an Italian neurologist most of whose work was undertaken in the USA under the mentorship and then collaborative guidance of Viktor Hamburger [1900-2001], a renowned German-born embryologist/neurobiologist, who was forced in 1933 by the Nazi regime to remain in the USA after a study leave. For discoveries on growth factors, Levi-Montalcini, who is now 102 years of age, was co-awarded a Nobel Prize with Stanley Cohen, an American biochemist. Many believe that Hamburger should have shared this award.

${ }^{19}$ Among the many neurophysiologists and neuropharamcologists who contributed substantially to the argument about chemical vs. electrical transmission at the NMJ after du Bois-Reymond (1874), Grundfest (1957) singled out eight for special mention (i.e., in addition to the others mentioned in his review). This group included in the chronological order of their possibly most significant NMJ article: Gotch (1900), Thomas R. Elliot [1877-1961] (1905), Keith Lucas (1907), Siegfried Garten [1871-1923] (1910), Louis Lapicque [1866-1952] (1926), Alfred Fessard [1900-1982] (1947), Stephen W. Kuffler [1913-1989] (1949). He also lauded Walter B. Cannon [1871-1945] for his work on the pharmacology of the NMJ, including, in particular his and his trainees work on curare (see Cannon, 1939 ; Valenstein, 2002), which included notable contributions by Arturo Rosenblueth [1900-1970], a Mexican physiologist who helped found the science of cybernetics.

\section{Acknowledgements}

F.C. presented some of the above in an historical session chaired by J.-G.B. at a meeting of the International Motoneuron Society, "Towards translational research in motoneurons," Paris, FRA, July 91-3, 2009 (Organizers: C.J. Heckman, Didier Orsal, Jean-François Perrier, Daniel Zytnicki). For the preparation of our article we thank Nga Nguyen (AHSC Library, University of Arizona) for her library research and Wulfila Gronenberg (University of Arizona) for helping with several translations of German into English. We also thank Douglas Stuart for helpful comments in various drafts of this article. 


\section{References}

Adrian, E.D., 1913. Wedensky inhibition in relation to the 'all-or-none' principle in nerve. J. Physiol. (London) 46, 384-412.

Adrian, E.D., 1914. The all-or-none principle in nerve. J. Physiol. (London) 47, 460-474.

Adrian, E.D.,1926. The impulses produced by sensory nerve endings. J. Physiol. (London) 61, 49-72.

Adrian, E. D., 1934. Cambridge 1902-1914. In: Fletcher, W.M. (Ed.), Keith Lucas. Heffer, Cambridge, pp. 89-108.

Adrian, E.D., Forbes, A., 1922 . The all-or-nothing responses of sensory nerves fibres. J. Physiol. (London) 56, 301-330.

Adrian, E.D., Lucas, K., 1912. On the summation of propagated disturbance in nerve and muscle. J. Physiol. (London) 44, 68-122.

Adrian, E.D., Zotterman, Y., 1926a. The impulses produced by sensory nerve endings. Part 2. The response of a single end organ. J. Physiol. (London) 61, 151-171.

Adrian, E.D., Zotterman, Y., 1926b. The impulses produced by sensory nerve endings. Part 3. Impulses set up by touch and pressure. J. Physiol. (London) 61, 465-483.

Barbara, J.-G., 2007. Louis Ranvier (1835-1922): the contribution of microscopy to physiology and the renewal of French general anatomy. J. Hist. Neurosci. 16, 41331.

Barbara, J.-G., 2008. Diversité et évolution des pratiques chirurgicales, anatomiques et physiologiques du cerveau au XVIIle siècle [Diversity and progress in the practical procedures of surgery, anatomy and physiology of the brain in the 18th $\mathrm{C}$ ]. In: Cherici, C., Dupont, J.C. (Eds.), Querelles du Cerveau à l'Âge Classique (XVleXVIIle siècles) [Polemics on The Brain in the 16th-18th C]. Vuibert, Paris.

Barbara, J.-G., 2009. Claude Bernard et la question du curare: enjeux épistémologiques et l'émergence d'une nouvelle physiologie [Claude Bernard and his successors on curare: epistemological questions at stake] . J. Soc. Biol. 203, 227-209.

Barbara, J.-G., 2010. La naissance du neurone [The birth of the neuron]. Vrin, Paris.

Barbara, J.-G., 2010. Le paradigme neuronal [The neuronal paradigm]. Hermann, Paris.

Barde, Y.-A., Edgar, D., Thoenen, H., 1982. Purification of a new neurotrophic factor in mammalian brain. EMBO J. 1, 549-553.

Bernard, C., 1857. Leçons sur les Effets du Substances Toxiques et Médicamenteuses [Lecture on the Effects of Toxic and Medicinal Substances]. Baillière, Paris.

Bernard. C., 1858. Leçons sur la Physiologie et la Pathologie du Système Nerveux [Lectures on the Physiology and Pathology of the Nervous System]. Baillière, Paris.

Bernard, C., 1864/65. Cours de médecine expérimentale [PROVIDE TRANSLATION]. Rev. Cours Sci. (Paris) 3, 242-246.

Bernard, C., 1865. Introduction à I,Étude de la Médecine Expérimentale [Introduction to the Study of Experimental Medicine]. GF Flammarion, Paris. (New edition in 1984; first English translation by H. C. Greene, published by Macmillan, London 1927; reprinted in 1949).

Borelli, G., 1680/1989. De Motu Animalium [On the Movement of Animals]. (1989 translation by P. Maquet). Springer-Verlag, Berlin.

Brazier, M.A.B., 1959. The historical development of neurophysiology. In: Field, J., Magoun, H.W., Hall, V.E. (Eds.) Handbook of Physiology, Neurophysiology. Vol. 1. American Physiological Society, Washington, D.C., pp. 1-58.

Brazier, M.A.B., 1984. A History of Neurophysiology in the 17th and 18th Centuries: From Concept to Experiment. Raven, New York.

Brazier, M.A.B., 1988. A History of Neurophysiology in the 19th Century. Raven, New 
York.

Brownstone, R.M., Barbara, J.-G., Clarac, F., Duchateau, J., Enoka, R.M., Stuart, D.G., 2011. Epilogue: whither motoneurons? Brain Res. Rev. This issue.

Buller, A. J., Eccles, J.C., Eccles, R.M., 1960a . Differentiation of fast and slow muscles in the cat hind limb. J. Physiol. (London) 150, 399-416.

Buller, A.J., Eccles, J.C., Eccles, R.M., 1960b . Interaction between motoneurones and muscles in respect of the characteristic speeds of their responses. J. Physiol. (London)150, 417-439.

Burke, R.E., 1981. Motor units: anatomy, physiology and functional organization. In: Brookhart J.M., Mountcastle, V.B., Brooks, V.B., (Eds.). Handbook of Physiology, Sec. 1: Vol. II, Pt 1. The Nervous System: Motor Control. Am. Physiol. Soc., Bethesda, MD, pp. 345-422.

Canguilhem, G., 1977. La Formation du Concept de Réflexe aux XVIle et XVIIle Siècles [Development of the Concept of the Reflex in the 17th and 18th Centuries]. (Second revised edition). Vrin, Paris.

Cannon, W.B., 1939. The argument for chemical transmission of nerve fibers. Science 90, 521-527.

Chakkalakal, J.V., Nishimune, H., Ruas, J.L., Speigelman, B.M., Sanes, J.R., 2010. Retrograde influence of muscle fibers on their innervation revealed by a novel marker for slow motoneurons. Development 137, 3489-3499.

Charcot J.M., Gombault A., 1881. Note relative à I 'étude anatomique de la néphrite saturnine expérimentale [Note on the anatomy of experimental lead poisoning nephritis ] Archiv. Physiol. Norm. Pathol. 1, 126.

Clarac F., Pearlstein E., 2007. Invertebrate preparations and their contribution to neurobiology in the second half of the 20th century. Brain Res. Rev. 54, 113-161.

Clarac, F., 2010. Albert Gombault 1844-1904. J. Neurol. 257, 307-308.

Clarac, F., Barbara, J.-G., 2011. The emergence of the "motoneurone concept": from the early 19th $\mathrm{C}$ to the beginning of the 20th C. Brain Res. Rev. This issue.

Clark, D.A., 1931. Muscle counts of motor units: a study in innervation ratios. Am. J. Physiol. 96, 296-304.

Clark, D.M., 2006. Descartes: a Biography. Cambridge University Press, Cambridge.

Cobb, M., 2002. Exorcing the animal spirits: Jan Swammerdam on nerve function. Nat. Rev. Neurosc., 35, 395-400.

Cook, J.S. 1986. "Sparks" vs. "soup": a scoop for soup. News Physiol. Sci., 1, 206-208.

Couteaux, R., 1998. Early days in the research to localize skeletal muscle acetylcholinesterases [Les premières étapes des recherches dans la localisation des acétylcholinestérases du muscle squelettique]. J. Physiol. (Paris) 92, 59-62

Daremberg, C. (Translator) 1854. Oeuvres Anatomiques, Physiologiques et Médicales de Galien, Tome 1 [The Anatomical, Physiological and Medical Works of Galen, Vol. 1]. (Translated from Greek into French). Baillière, Paris.

David, S., Aguayo, A.J.,1981. Axonal elongation into peripheral nervous system "bridges" after central nervous system injury in adult rats. Science 214, 931-933.

Debru, A., 1996. Le Corps Respirant : la Pensée Physiologique Chez Galien [The Breathing Body: Galen's Physiological Thought]. Brill, Leiden/New York.

Delaroche, D.D., 1778. Analyse des Fonctions du Système Nerveux, pour Servir d'Introduction à un Examen Pratique des Maux de Nerfs [Analyses on the Functions of Nerves as an Introduction to the Examination of Nervous Diseases]. Du Villard Fils \& Nouffer, Geneva.

Dobson, J.F., 1927. Erasistratus. Proc. R. Soc. Med. 20, 825-832.

Doyère, L., 1840. Memoire sur de les tardigrades [Memoir on tardigrades]. Ann. Sci. 
Natl. Ser 2 (Zool.) 14, 269-361.

du Bois-Reymond, E., 1874. Gessammelte Abhanndlungen zur allgemeinen Muskelund Nervenphysik. Bd. 2 [Compiled Essays on the Physics of Muscle and Nerves. Vol. 2]. Veit, Leipzig.

Dubowitz, V., 1967. Cross-innervated mammalian seletal muscle: Histochemical, physiological and biochemical observations; J. Physiol. (London)1903, 481-496.

Duchateau, J., Enoka, R.M., 2006. Extracellular recording of human motor unit discharge: origin and insights into the integrated motor system. Brain Res. Rev. This issue.

Dürer, A. 1528. Vier Bücher von menschlicher Proportion [Four Books on Human Proportions].

See: http://www.nlm.nih.gov/exhibition/historicalanatomies/durer_home.html

Eccles, J.C., 1946. An electrical hypothesis of synaptic and neuromuscular transmission. Ann. N.Y. Acad. Sci. 47, 429-455.

Eccles, J.C., 1953. The Neurophysiological Basis of the Mind - The Principles of Neurophysiology. Clarendon Press, Oxford.

Eccles, J.C., Sherrington, C.S., 1930. Numbers and contraction values of individual motor units examined in the same muscles of the limb. Proc. R. Soc. B 106, 326357.

Elliott, T.R., 1905. On the action of adrenaline. J. Physiol. (London) 32, 401-467.

Fessard, A., 1947. Récherches sur le functionnement des organs electriquques. 1. Analyse des formes de décharge obtenues par divers procedés d'excitation [Studies on the function of electric organs. 1. Analysis of forms of discharge obtained by different methods]. Arch. Int. Physiol. 55, 1-46.

Finger, S, 1994. Origins of Neuroscience. Oxford University Press, New York.

Fletcher, W.M., Keith-Lucas, A. (Eds.), 1934. Keith Lucas. Heffer,Cambridge. (Originally completed in 1916 but not published until after Fletcher's demise).

Flourens, M.-J.-P., 1828. Expériences sur la réunion ou cicatrisation des plaies de la moelle épinière et des Nerfs [Experiments on the healing of the wounds of the nerves and the spinal cord]. Ann. Sci. Natur. Ser. 1 13, 113-122.

Fokin, S.H., 2001. A love 50 years long: Professor V.A. Dogiel as protistologist. Protist. 152, 379-387.

Fontana, F., 1781/1807. Treatise on the Venom of the Viper; on the American Poisons; and on the Cherry Laurel; and Some Other Vegetable Poisons, to Which Are Annexed, Observations on the Primitive Structure of the Animal Body; Different Experiments on the Reproduction of the Nerves; and a Description of a New Canal of the Eye. 2 Vols. (1807 English translation by J. Skinner). J. Murray, London. (Published previously (1781) in Florence).

Forbes, A. 1916. Keith Lucas. Science 44, 808-810.

Forbes, A., Thacher, C., 1920, Amplification of action currents with the electron tube in recording with the string galvanometer. Am. J. Physiol. 52, 409-471.

Forbes, A., 1939. Problems of synaptic function. J. Neurophysiol. 2, 465-472.

Funakoshi, H., Frisén, J., Barbarny, G., Timmusk, T., Zachrisson, O., Verge, V.M.K., Persson, H., 1993. Differential expression of mRNAs for neurotrophins and their receptors after axotomy of the sciatic nerve. J. Cell Biol. 123, 455-465.

Galen, C., 2nd C B.C./1916, On the Natural Faculties. (Edited and translated from Latin into English by A.J. Brock). Loeb Classical Library, Edinburgh.

Galen, C., 1556. Du mouvement des muscles [On the movement of muscles]. (Translated from Latin into Middle French by J. Canape). Sabon, Lyon. 
Garten, S., 1910. Die Produktion von Elektrizitat [The Production of Electricity]. Handb. Vergl. Physiol. 3 pt. 2, 105-224.

Gasser, H.S., Newcomer, H.S., 1921. Physiological action currents in the phrenic nerve. An application of the thermionic vacuum tube to nerve physiology. Am. J Physiol. 57, 1-26.

Gotch, F. 1900. The physiology of electric organs. In: Schäfer, E.A., (Ed.), Textbook of Physiology, Vol. 2. Macmillan, London.

Gotch, F. 1902. The submaximal electrical response of nerve to a single stimulus. J. Physiol (London) 28, 395-416.

Gotch, F., Burch, G.J., 1898. The electrical response of nerve to two stimuli. J. Physiol (London) 24, 395-426.

Gourevitch, D. (Trans./Ed.), 1994. Hippocrate - De l'Art Médical [Hippocrate -The Art of Medicine]. Librairie Générale Française, Paris. (Another translation into French is: Jouanna, J., Magdelaine, C. (Trans./Eds.), 1999. Hippocrate. L’Art de la Médecine [Hippocrate, the Art of Medicine]. GF Flammarion, Paris.

Grafstein, B., 1969. Axonal transport: communicationbetween soma and synapse. Advanc. Biochem. Psychopharm. 1, 11-25.

Grundfest, H., 1957. Excitation at synapses. J. Neurophysiol. 20, 316-324.

Gutmann, E., 1942. Factors affecting recovery of motor function after nerve lesions. J. Neurol. Psychiat. 5, 81-95.

Hirokawa, N., Niwa, S., Tanaka, Y., 2010. Molecular motors in neurons: transport mechanisms and roles in brain function, development, and disease. Cell 68, 610638.

Hodgkin, A., 1979. Edgar Douglas Adrian, Baron Adrian of Cambridge. 30 Novemebr 1889-4 August 1977. Biogr. Mems. Fell. R. Soc. 25, 1-78.

Howard, J.F. Jr., 2003. Structure and function of the neuromuscular junction. In: Stalberg, E., (Ed.), Handbook of Clinical Neurophysiology 2, 27-48. (Also available at: http://preview.tinyurl.com/5sz89r5).

Kernell, D., 2006. The Motoneurone and its Muscle Fibres. Oxford University Press, Oxford.

Krause, W., 1863. Über die endigung der muskelnerven [On the ending of the muscle nerve]. Z. Rationelle Med., 85, 461-464.

Kuffler, S.W., 1949. Transmitter mechanisms at the nerve-muscle junction. Arch. Sci. Physiol. 3, 585-601.

Kühne, W., 1887. Neue Untersuchen über motorische Nervenendigun [New studies about the motor nerve ending] Ztschr. Biol. 23, 1-148.

Kühne, W. 1888. Croonian Lecture - On the origin and causation of vital movement [Über die Enstehung der vitalen Bewegung]. Proc. R. Soc. London 44, 427-448.

Koliatsus, V.E., Clatterbuck, R.E., Winslow, J.W., Cayouette, M.H., 1993. Evidence that brain-derived neurotrophic factor is a trophic factor for motor neurons in vivo. Neuron 10, 359-367.

Langley, J.N., 1918. On the separate suture of nerves in nerve trunks. Brit. Nerv. J. 1, 45-47.

Lapicque, L., 1926. L'excitabilité en Function du Temps [Excitability as a Function of Temperature]. Les Presses Universitaires, Paris.

Levi-Montalcini, R., 1987. The nerve growth factor 35 years later. Science 337, 11541162.

Lucas, K., 1905. On the gradation of activity in a skeletal muscle-fibre. J. Physiol. (London) 33, 125-137.

Lucas, K., 1907.The excitable substances of amphibian muscle. J. Physiol. (London) 
$36,113-135$.

Lucas, K., 1909 . The "all or none" contraction of the amphibian skeletal muscle fibre. J. Physiol. (London) 38, 113-133.

Lucas, K., 1911. On the transference of the propagated disturbance from nerve to muscle with special reference to the apparent inhibition described by Wedensky. J. Physiol. (London) 43, 46-90.

Maclntosh, B.R., Gardiner, P.F., McComas, A.J., 2006. Skeletal Muscle - Form and Function. 2nd. Edit. Human Kinetics, Champaign, IL.

Marcum, J.A., 2006. 'Soup' vs. 'sparks': Alexander Forbes and the synaptic transmission controversy. Ann. Sci. 63, 139-156.

Marshall, C.F., 1890 Observations on the structure and distribution of striped and unstriped muscle in the animal kingdom, and a theory of muscular contraction. Quart. J. Micr. Sc., 28, 75-107.

McComas, A.J., 1978. Neuromuscular Function and Disorders. Butterworths, London.

Molgó J, Colasante C, Benoit E, Poulain B., 2009. Rappels structuraux et fonctionnels de la jonction neuromusculaire squelettique [A reminder of the structure and function of the skeletal neuromuscular junction]. Ann. Dermatol. Venereol.136 Suppl. 4:S5560.

Molnar, Z., 2004 . Thomas Willis (1621-1675), the founder of clinical neuroscience. Nat. Rev. Neurosci. 5, 329-335.

Needham, D.M., 1926. Red and white muscle. Physiol. Rev. 6, 1-27.

Nissl, F., 1892. Uber die veranderungen der Ganlienzellen am Facialiskern des kaninchens nach Aureissung der nerven [About changes in the facial nucleus of the rabbit after severing the nerves]. Allg. Z. Psychiatr. Ihre. Grenzgeb. 48, 197-198.

Ochs, S, 2004 . A History Of Nerve Functions. Cambridge University Press, New York.

Offray de La Mettrie, J., 1748. L'homme Machine [Man a Machine]. For the 1999 translation by J. Bennett see: http://www.earlymoderntexts.com/f_mettrie.html

Olmsted, J.M.D., 1944. François Magendie: Pioneer in Experimental Physiology and Scientific Medicine in 19th Century France. Henry Schuman, New York.

Palay, S.L., Palade, G. 1955. The fine structure of neurons. J. Biophys. Biochem. Cytol. 1, 69-88.

Pette, D., 2001. Historical perspectives: plasticity of mammalian skeletal muscle. J. Appl. Physiol. 80, 1119-1124.

Ramón y Cajal, S., 1928. Degeneration and Regeneration of the Nervous System. Translated and edited by Raoul M. May. Oxford University Press, London, 2 vols.

Ranvier, L., 1873. Proprieties et structures differentes des muscles rouges et des muscles blanc, chez lapins et chez les raies [Properties and structures of different red and white muscles of the rabbit and ray fish]. C. R. Hebd. Acad. Sci (Paris) 77: 1030-1043.

Ranvier L., 1874. De quelques faits relatifs à l'histologie et à la physiologie des muscles striés [Some facts on the histology and the physiology of striated muscles]. Arch. Physiol. 1, 5-15.

Ranvier L., 1875. Traité Technique d'Histologie [Technical Treatise on Histology]. Savy, Paris.

Reichert, K. B., 1851. Ueber das Verhalten der Nervenfasern bei dem Verlauf der Vertheilung und Endigung in einen Hautmuskel des Frosches (Rana temporaria) [About the behavior of nerve fibers during their distribution and termination in a skin muscle of the frog (Rana temporaria)]. Arch. f. Anat., Physiol. u. Wissensch. Med. 19, 29-73. (Note: the original article has a misprint on the title page: i.e., K.E. Reichert rather than the correct K.B. Reichert). 
Riva, A., Conti, G., Solinas,P., Loy F., 2010.The evolution of anatomical illustration and wax modelling in Italy from the 16th to early 19th centuries. J. Anat. (London) 216, 209-222.

Rubin, R.P., 2007. A brief history of great discoveries in pharmacology: in celebration of the centennial anniversary of the founding of the American Society of Pharmacology and Experimental Therapeutics. Pharm. Rev. 59, 289-359.

Salpeter, M. (Ed.), 1987. The vertebrate neuromuscular junction. Neurology and Neurobiology Series 23. Alan R. Liss, New York.

Schiaffino, S. and Reggiani, C.,1996. Molecular diversity of myofibrillar proteins: gene regulation and functional significance. Physiol. Rev. 76, 371-423.

Schoenfeld, R.L., 2002. From Eintoven's galvanometer to single-channel recording. IEEE Eng Med Biol Mag. 21, 90-96.

Smith, D.S., 1961. Reticular organizations within the striated muscle cell: an historical survey of light microscopical studies. J.. Biophys. Biochem. Cytol. 10, 61-86.

Sperry, R.W., 1941. The effect of crossing nerves to antagonistic muscles in the hind limb of the rat. J. Comp. Neurol. 75, 1-19.

Sperry, R.W., 1945. The problem of central nervous reorganization after nerve regeneration and muscle transplantation. Quart. Rev. Biol. 20, 311-369.

Sperry, R.W., 1947. Effect of crossing nerves to antagonistic limb muscles in the monkey. Arch. Neurol. Psychiat. 58, 452-473.

Stuart, D.G., Brownstone, R.M., 2011. The beginning of intracellular recording in spinal neurons: facts, reflections, and speculations. Brain Res. Rev. This issue.

Stuart, D.G., Zigmond, M.J., (Eds.), 2006. The contributions of John Carew Eccles to contemporary neuroscience. Prog. Neurobiol. 78, 135-326.

Stuart, D.G., Clarac, F., Jean-Gaël Barbara, J-G, Brownstone, R.M., Duchateau, J., Roger M. Enoka, R.M., 2011. Paths of discovery in motoneuron neurobiology. Brain Res. Rev. This issue.

Swash, M., 2008. The innervation of muscle and neuron theory. Neuromuscul. Dis. 18, 426-430.

Sykes A.H., 2004. Father and Son Physiologists, Servants of Medicine. William Sessions, York, GBR.

Valenstein, E.S., 2002. The discovery of chemical neurotransmitters. Brain Cogn. 49, 73-95.

van Gehuchten, A., 1886. Etude sur la structure intime de la cellule musculaire striée. [Study of the detailed structure of the striated muscle cell]. Cellule 2, 293-453.

Vesale (Vesalius), A, 1543. De Humani Corporis Fabrica Libri Septem [On the Fabric of the Human Body in Seven Books]. Johannes Oporinus (original publisher), Basel. (For an English translation see: Richardson, W,F., Carman, J.B., 1998-2009. Andreas Vesalius-On the Fabric of the Human Body, 5 Vols. Norman Publishing, San Francisco.

von Haller, A., 1747/1966. First Lines of Physiology [(Primae lineae physiologiae]. Johnson Reprint Corp., New York. (Translated from the original Latin edition, with an introduction by L.S. King).

von Helmholtz, H., 1850a. Ueber die Fortpflanzungsgeschwindigkeit der Nervenreizung [On the propagation velocity of the nerve irritation]. In: Report of the Notice to the Appropriate Negotiations of the Royal Prussian Academy of Sciences in Berlin. pp.14-15.

von Helmholtz, H., 1850b. Note sur la vitesse de propagation de l'agent nerveux dans les nerfs rachidiens [Note on the propagation velocity of the nervous agent in spinal nerves]. C. R. Hebd. Seances Acad. Sci. 30, 204-206. 
von Helmholtz, H., 1851. Deuxième note sur la vitesse de propagation de l'agent nerveux [Second note on the propagation velocity of the nervous agent] C. R. Hebd. Seances Acad. Sci. 33, 262-265.

Vrbova, G., Gordon, T., Jones, R. 1995 . Nerve-Muscle Interaction, 2nd Edit. Chapman Hall, New York.

Vulpian, A., 1863. Recherches expérimentales sur la réunion bout à bout des nerfs de fonctions différentes [Experimental research on the fusion of nerves with different functions]. J. Physiol. Hom. Anim. 6, 476-516.

Wedensky, N. E., (1985/86). Ueber einige Beziehungen zwischen der Reizstärke und der Tetanushöhe bei indirecter Reizung [About some correlations between stimulus strength and tetanus amplitude during indirect stimulation]. Arch. f. d. ges. Physiol. 36, 69-72.

Weiss, P.A., 1948. Experiments on the mechanism of nerve growth. J. Exp. Zool. 107, 315-396.

Wiersma, C.A.G., Ed., 1967. Invertebrate Nervous Systems: Their Significance for Mammalian Neurophysiology. University of Chicago Press, Chicago.

\section{Figure legends}

Fig. 1 - Ecorché from the work of Vesalius (also known as Vesale) It shows the muscles of the generalized man exposed by removal of the skin. (From Vesale (1453) with permission of the publisher).

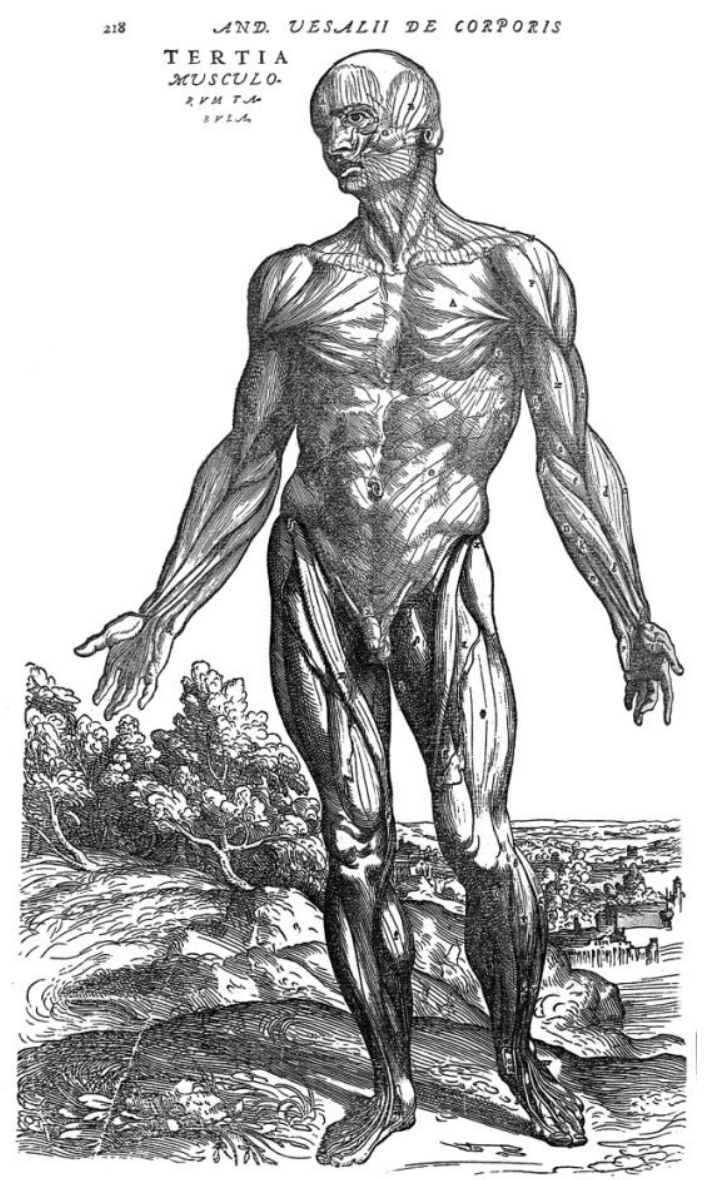


Fig. 2 - A drawing by Descartes of two muscles (A, E) operating on the human eye. The drawing shows the path of animal spirits (c, b) from the brain to the muscles with opening of membranes directing the animal spirits on one side or the other. According to Descartes, muscles A and E contracted in opposition (antagonist muscles) because the inflows of animal spirits occurred alternatively, making the eye move one way or the other (From Descartes (2001) with permission of the publisher).

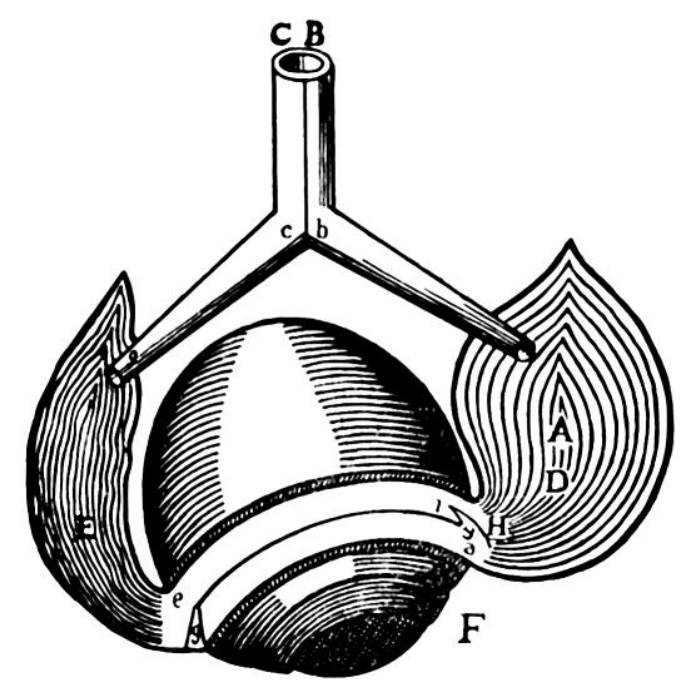

Fig. 3 - A drawing by von Helmholtz of his technique for measuring nerve conduction. The frog gastrocnemius muscle $(m)$ is attached and its nerve $(n)$ is stimulated at different locations near or far away from the muscle by the electrode (e) and the reference electrode ( $r$ ). For each stimulation, the delay is measured between the stimulation and the muscle contraction measured by a dynamometer attached to the hook (d). By comparing the different delays of the nerve stimulations near or far away from the muscle, the conduction speed of the nerve could be estimated (From Helmholtz, (1850) with permission of the publisher).

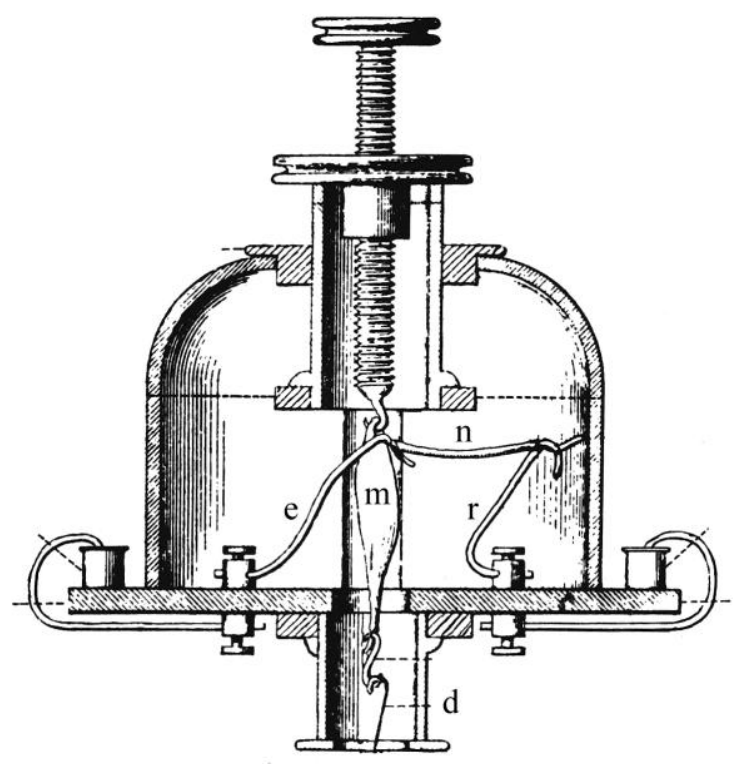


Fig. 4 - Drawings by Keith Lucas in his study that proved operation of the all-or-none law in skeletal muscle fibers. (A) His preparation of the cutaneus dorsi muscle of the frog. Note that the size of the muscle (held down with a pin) was exaggerated. His descriptor numbers and abbreviations included: 1 , the nerve to cutaneus dorsi; 2 , the branch of the iliohypogastric nerve going to the obliquus externus; $\mathrm{VII} / \mathrm{VIII} / \mathrm{IX}$, branches of the plexus to which the electrodes were applied; XXXX, points at which various braches of the plexus were cut; lliohyp, trunk of the iliohypogastreic nerve; Obl.ext, obliquus externus; Rect. Fem., rectus femoris; Vast. Ext., vastus externus. (B) The experimental set-up. His descriptors included: $C$, the test muscle; $D$, the recording lever, which carried a mirror; $E$, a lens used to focus light on the recording drum; $F$, electrodes applied to the VIIth nerve ; G-K, rods on which the apparatus was supported. The inset shows Lucas' plot of the relation between stimulus current strength ( $X$ axis measured as the distance in $\mathrm{mm}$ between the primary and secondary coils of his stimulating apparatus) and the magnitude of the muscle's contraction ( $\mathrm{Y}$ axis measured as the extent of the shortening contraction in $\mathrm{mm}$ ). Lucas built most of his apparatus in a machine shop at his home. (From Lucas (1909) with permission of the publisher).

A

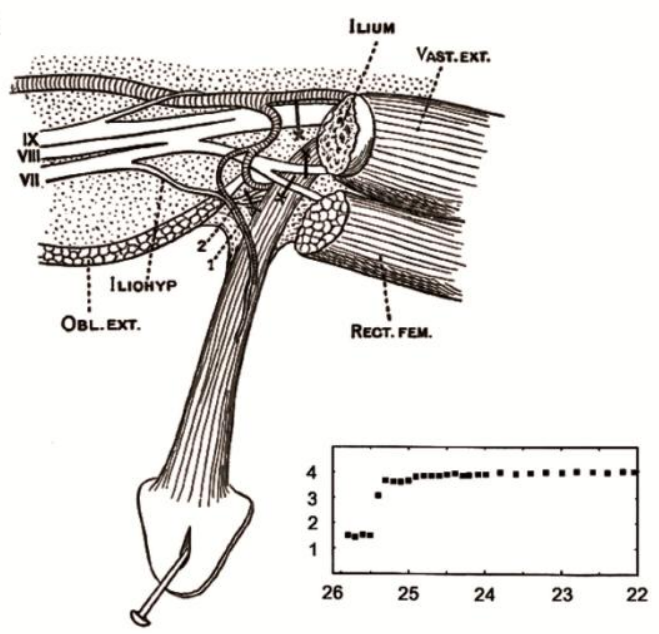




Fig. 5 - Examples of Ranvier's anatomical work on the NMJ. (A) A drawing of a terminal nerve arborization from the hind limb of a green lizard stained with the Löwit method. (B) A drawing of two dissociated muscle fibers from a rabbit intercostal muscle. They were injected with osmic acid, and stained with picrocarminate. Two endings of a nerve $(N)$ are shown, one is a side view $(p)$ and the other one is a side view (p'). (From Ranvier (1875) with permission of the publisher).

A
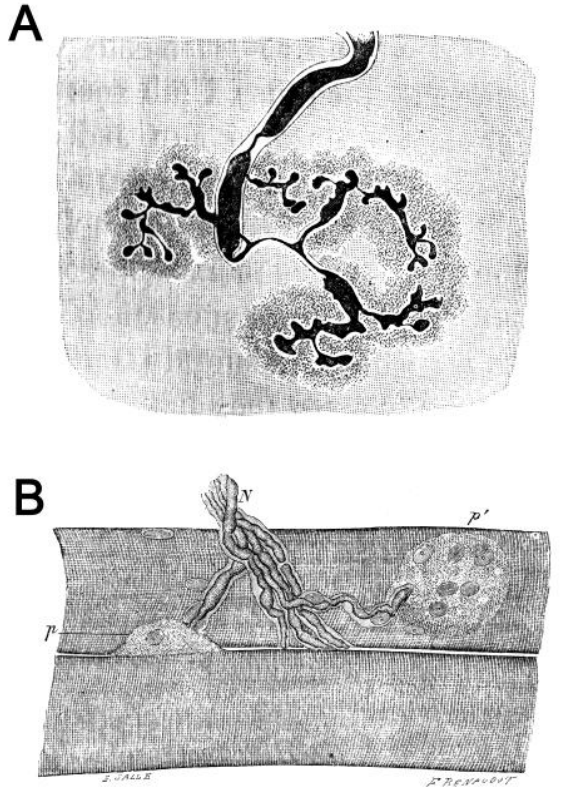

Fig. 6 - Drawing by Waller showing spinal nerve fibers (nf), two of them degenerating (D) with myelin fragmentation and the formation of droplets (d) (From Sykes (2004) with permission of the publisher).

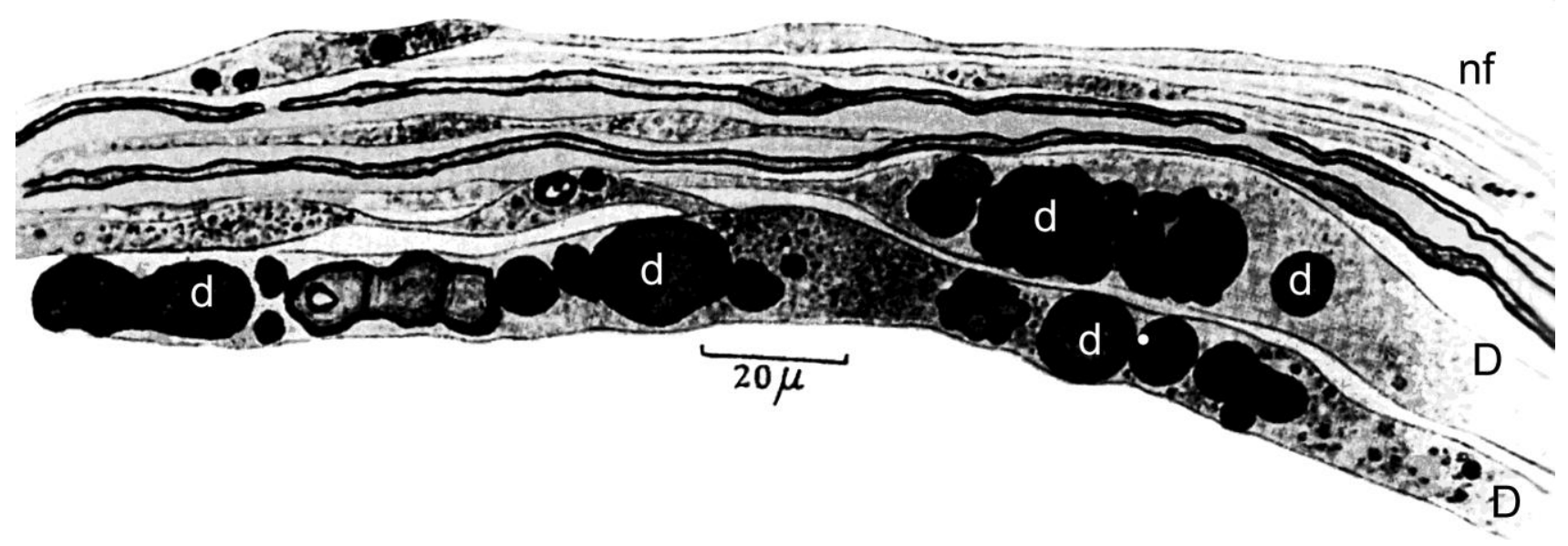


Fig. 7 - A conceptual three-dimensional summary of interrelationships between some physiological, morphological, and histochemical properties of the MUs of the cat medial gastocnemius muscle. Note that the MUs' muscle component properties include: $Y$ axis-peak tetanic force; $X$ axis-twitch contraction time, myofibrillar ATPase staining; $Z$ axis-metabolic enzyme patterms (low to high oxidative capacity), resistance to fatigue, muscle fiber diameter. The MN properties include: $X$ axis-axonal conduction velocity, duration of afterhyperpolarization, response to polysynaptic sural nerve stimulation; $Z$ axis, excitatory post synaptic (EPSP) response to spindle group la input. The author's further explanation included: "It should be clear that this summary somewhat distorts reality in that the various features specified are not all distributed in exactly the way displayed, but the general trends are illustrated." (From Burke (1981) with permission of the publisher).

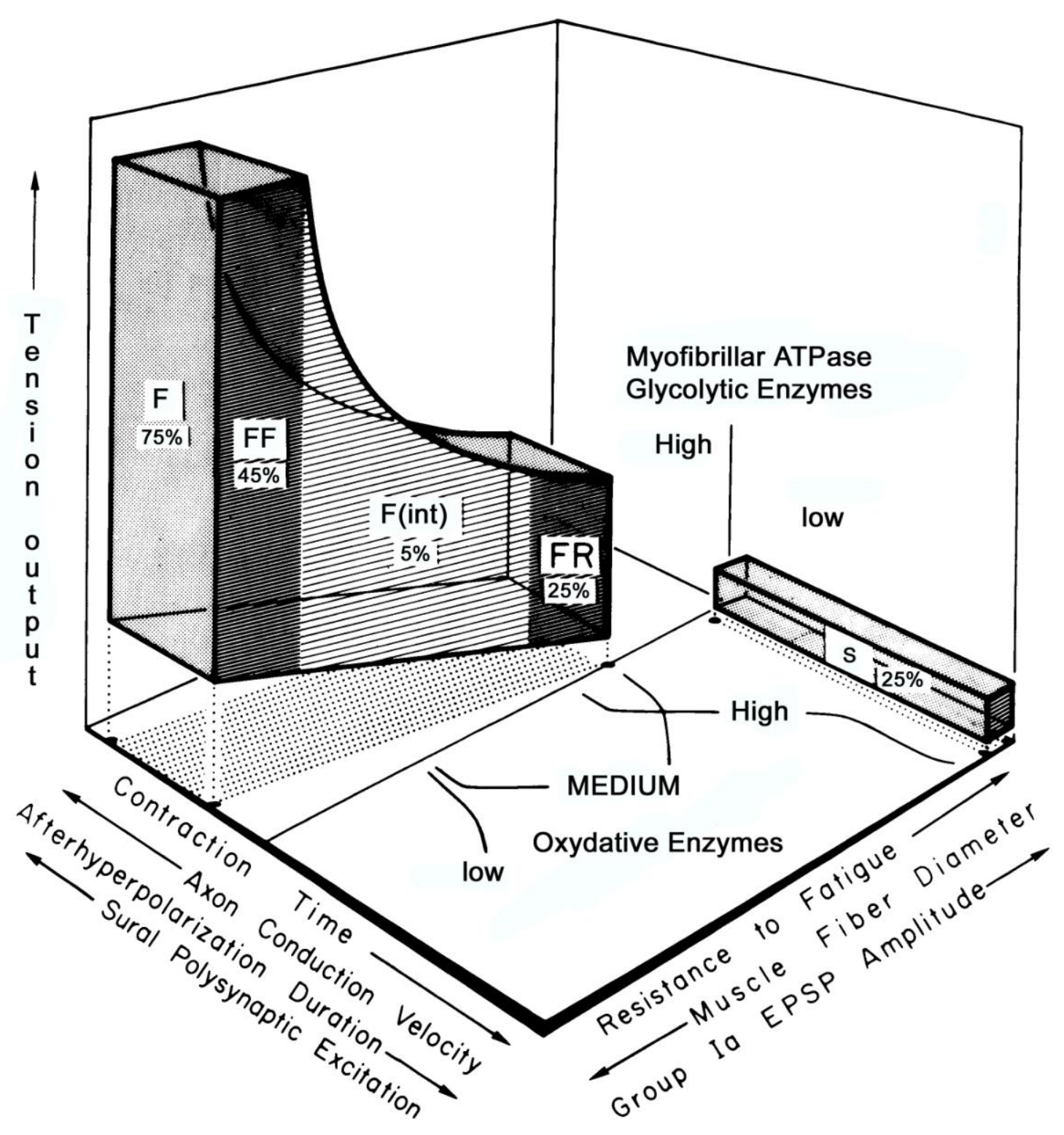


Fig. 8 - A summary by McComas (1978) that included the 1892 findings of Nissl, which initiated the study of muscle-to-nerve trophism. The figure legend (with modified lettering) reads: "Changes in motoneurone $(M)$ following interruption of its axon. (A) shows a normal motoneurone (M) innervating several muscle fibres. (B) represents situation about 7 days after axotomy (at arrows); note swollen motoneurone soma with displaced nucleus and enlarged nucleolus. Nissl substance is dispersed and dendrites have retracted. Distal axon stumpis is degenerating and muscle fibres have started to atrophy. The glial cell $(\mathrm{G})$ close to the motoneurone is also enlarged. If reinnervation of muscle is successful normal neuronal architecture is restored (D), though the axon now has shorter internodal segments. Failure to innervate is associated with progressive atrophy of motneurone (D) and, in some onstances, leads to eventual disappearance." (Relettered from McComas (1978) with permission of the publisher).

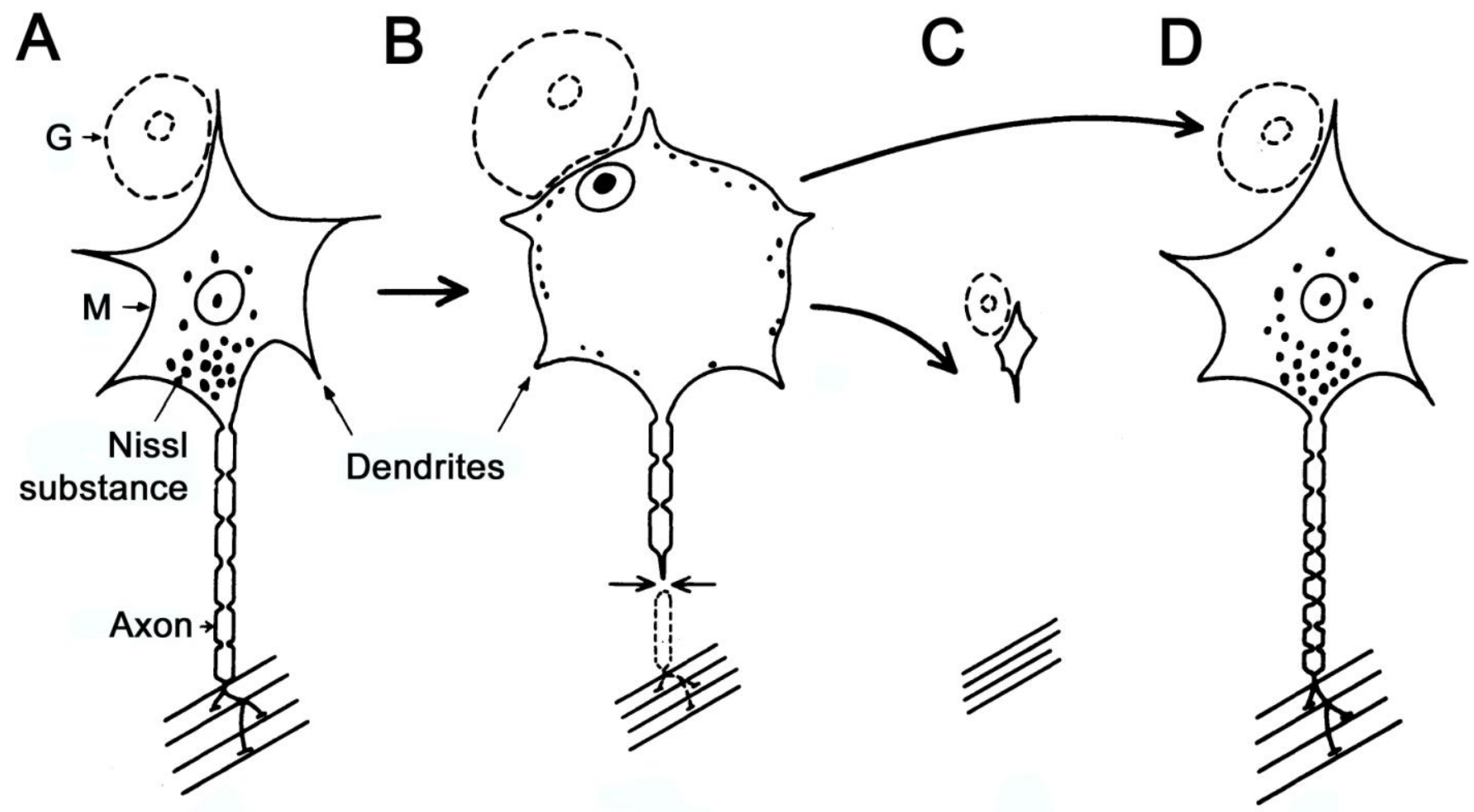


Fig. 9 - Trophic muscle fiber and CNS substances that act on MNs. They include two classes of neurotrophins, those resembling NGF and those resembling "cytokines." Abbreviations: BDNF, brain-derived neurotrophic factor (also derived in muscle fibers); CNTF, ciliary neurotrophic factor; FGF-5, fibroblast growth factor; GPA, growthpromoting factor; IGF, insulin-like growth factor; LIF, leukemia-inhibiting factor; NT, neurotrophin; P, "phosphate." CDF (choline acetyltranferase development factor) and several factors discovered after 2006 are not shown. Note also that the considerable Schwann cell effects on MNs are not discussed in this article. (From Maclntosh et al. 2006) with permission of the publisher).

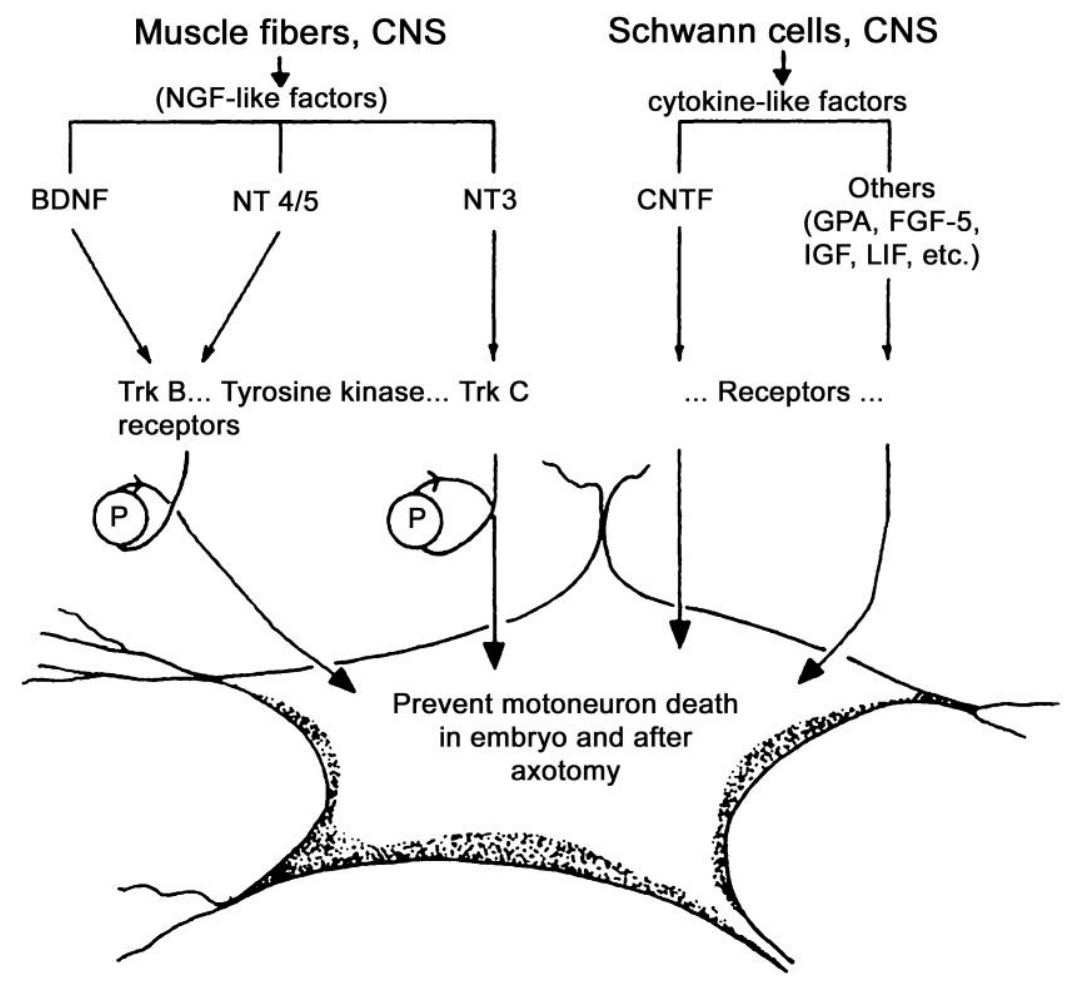

